
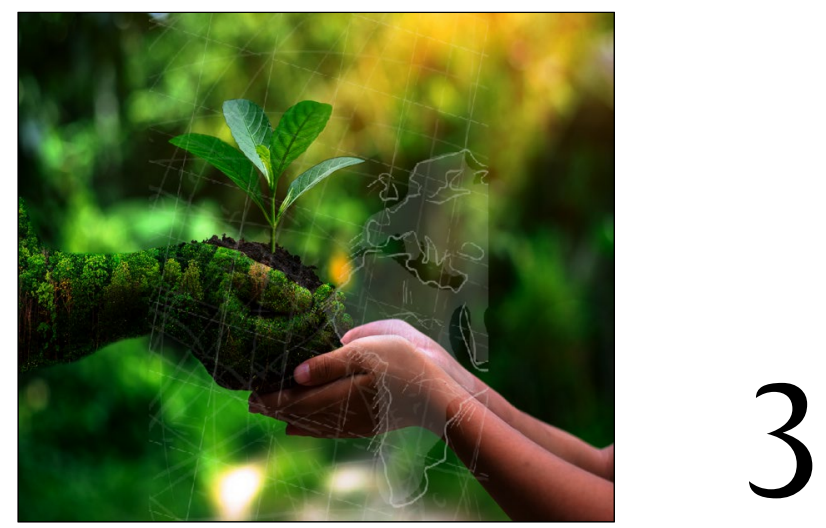

\title{
SUSTAINABLE ENERGY SYSTEMS IN AFRICA
}

\author{
Yacob Mulugetta and Lawrence Agbemabiese
}

\section{Introduction}

Ever since they attained political independence from colonial rule in the post-war years of the twentieth century, an 'energy imperative' has been at the core of the development agenda of African governments and their international development partners. Yet, despite more than 50 years of effort, energy systems on the continent remain largely 'under powered, inefficient, unequal' and ultimately unsustainable (Africa Progress Panel [APP], 2015). These failures account largely for the inability of most African countries to realise long-cherished goals of economic growth acceleration, the reduction and eventual elimination of poverty, and overall transitions to equitable improvements in standards of living. The few countries that have successfully transitioned from low- to middle-income status have done so by embarking on the well-beaten path that has been followed by the high-income, high-energy countries of the world: the build-up of centralised large-scale energy systems reliant on fossil and large hydro plants and associated infrastructure. 
Such conventional systems have fuelled rapid growth in recent years in several African countries while catalysing their integration into a global energy economy dominated by oil and gas. But, as explained in this chapter, energy systems of this sort are often not consistent with local needs, primarily because their design and construction have been directed (and continue to be governed) by a conventional paradigm of energy-environment-society relations that has proven problematic.

Africa thus confronts a dilemma; the resolution of which should be informed by recognising contemporary energy systems as themes of a complex energy story. One narrative presents the continent as undergoing transformation, with several countries following conventional development models that support a strategy of energising their agricultural and manufacturing sectors as part of an economic growth agenda, the creation of high-quality jobs on a path to achieving multiple SDGs. This story, however, has failed so far to provide viable explanations of, and solutions for, the persistent failure of most African countries to establish energy systems capable of delivering energy access and improved living conditions for all.

There is another largely marginalised side of the African energy story; one that exposes the realities of life in a larger world beyond the affluent enclaves of large cities. This is the world beyond the grid; a rural world inhabited by millions of people with the lowest per capita use of electricity in the world. People in such areas rely heavily on solid biomass as a main source of household energy for cooking. These areas are often represented by poor access to communication systems, underdeveloped transport networks, and inadequate educational and health systems. The areas also suffer from poor income generation, largely because of their inability to add value through agricultural processing. The lack of energy access due to the combined lack of skills, finance, institutions and policies is one of the key reasons for these poor development outcomes.

African governments and their development partners find themselves in a contradiction - between the critical nature of energy problems demanding quick solutions and interventions, and the complex energy system with so many dimensions. This requires careful planning and time-consuming studies that lead to concrete interventions with positive livelihood outcomes. The good news is that there are reasons to be optimistic about the future. Firstly, if stable enabling conditions are created there is a growing domestic economic wealth that can be unlocked and mobilised for energy investment. The growing demand for energy and the high tariffs that consumers already face (in addition to a frequent reliance on expensive electricity from back-up systems) creates opportunities for investment. Secondly, sub-Saharan Africa is rich in energy resources, even if it remains poor in energy supply. The region has significant and diverse primary energy resources, with sufficient coal, gas, geothermal, hydro, solar and wind resources to deliver 
more than 11 terawatts (TW) of capacity (Castellano, Kendall, Nikomarov \& Swemmer, 2015). Thirdly, the cost of energy technologies, especially renewable energy (RE) technologies, has come down rapidly over the past few years. In relation to this, the large capacity gaps in Africa's energy system creates openings for technological leap-frogging through policy innovation and experimentation. Here, the contribution that distributed energy systems can make needs to be explored further.

This chapter reviews the opportunities and constraints that African countries and communities face as they explore different energy options and delivery models, focusing on bottom-up and distributed energy systems.

\section{Africa’s energy system}

Nowhere is the critical nature of energy for development more pressing than in Africa. Part of the urgency is because the continent is under transformation, featuring favourable gross domestic product (GDP) growth rates over the past decade. According to International Monetary Fund (IMF) figures, overall, GDP grew at 4.6 percent in 2014, but slowed down to 3 percent in 2018 as commodity prices fell sharply and financing conditions became more difficult. It is expected rise to 3.6 percent in 2019 before stabilising at around 4 percent over the medium term (IMF, 2019). However, within this difficult picture, there is a considerable variation across the region, with growth in some countries holding steady at 7 percent or more in 2015 and 2016 supported by ongoing infrastructure investment and consumer spending. Several countries are also looking to boost their manufacturing sector as part of a programme of structural transformation by moving labour from low-productivity to high-productivity sectors. However, structural transformation is a double-edged sword. While it lays the foundation for high and sustained economic growth, it also requires increased energy use to maintain productivity necessitating significant investment in energy infrastructure.

Africa has significant resources. According to the United Nations Environment Programme (UNEP) publication Atlas of Africa Energy Resources, Africa has 7.5 percent of the world's proved gas reserves, 7.6 percent of its proved oil reserves and 3.6 percent of global coal reserves (of which South Africa alone accounts for 3.4 percent). The region's renewable energy resources are diverse, consisting of almost unlimited solar potential (10 TW), significant hydropower potential $(350 \mathrm{GW})$, wind $(110 \mathrm{GW})$, as well as geothermal resources $(15 \mathrm{GW})$ (UNEP, 2017:2). The challenge African countries face is how to develop the capability to harness sustainably their significant resources to meet their development objectives. At the moment, only a fraction of these resources are developed. 
The practice of widening access to modern energy services across sub-Saharan Africa is complex, largely due to the dual nature of the energy system itself where traditional and modern energy systems and practices co-exist (Sokona, Mulugetta \& Gujba, 2012). The total power generation capacity of the 48 sub-Saharan African countries, excluding the Republic of South Africa, stands at roughly 45 gigawatts (GW) (less than that of Turkey or Spain), and about a quarter of this capacity is not currently available, mainly due to ageing power plants and lack of maintenance. This case of crippling underinvestment means that more than 620 million people, amounting to nearly 70 percent of the total population, live without access to electricity. Only seven sub-Saharan countries, mostly concentrated in the west and southern African regions, now have electricity access rates exceeding 50 percent. With rapid population outpacing the rate of electrification, it is also the only region in the world where the number of people living without electricity is increasing. The International Energy Agency (IEA) calculates that between 2000 and 2014, the number of people without access to electricity increased in 37 countries, highlighting that any effort in widening energy access must take into account demographic as well as lifestyle changes. Furthermore, nearly 80 percent of those lacking access to electricity live in rural areas, which adds to the complexity of possible interventions, strategies and potential technical solutions (IEA, 2014). However, with the expected population growth of 1.5 billion by 2030 , future growth will be almost entirely urban, implying that the number of rural households for which access needs to be created will stabilise (World Bank, 2017c).

The history of electrification across Africa informs us that early electricity development across Africa came about for three major reasons: as a symbol of modernity for non-African settlers, as a source of power for mines and industry, or a stimulus for industrial development (Showers, 2011). As in Europe, electrification began with isolated, small-scale generators supplying farms, industries and municipalities, mostly built by the colonial powers and their associated private enterprises (Showers, 2011). These entities and industries were supported by the local supply of labour and skills, while most of its population remained dependent on subsistence agriculture. Today, African policymakers talk with confidence about the need for structural transformation. In some cases, deliberate policies are or are currently being implemented to support smallholder farmers to increase their energy use per unit of cultivated land by utlising better technologies, inputs and approaches. The lesson to take from history is that the electricity system in sub-Saharan Africa was designed as part of the integration of the continent into a global economic order, leaving the large rural, informal and subsistence production system with limited technological input from outside. The provision of modern energy services today has to be seen against this backdrop and contemporary presence of this historical legacy. 
According to the World Bank and partners, some gains are being recorded with an expansion of electricity in poorer countries, even the rate of electrification overtaking population growth for the first time in 2016 (World Bank, 2018). As shown in Figure 3.1, the reason behind this is the high and continued improvement in electricity access in East Africa, namely Kenya, Tanzania and Ethiopia. Helped by the rapidly declining cost of renewables, availability of targeted grants and the emergence of new business models, these countries have invested significantly in their electrification programmes as a means to support their ambitious economic transformation and social wellbeing goals.

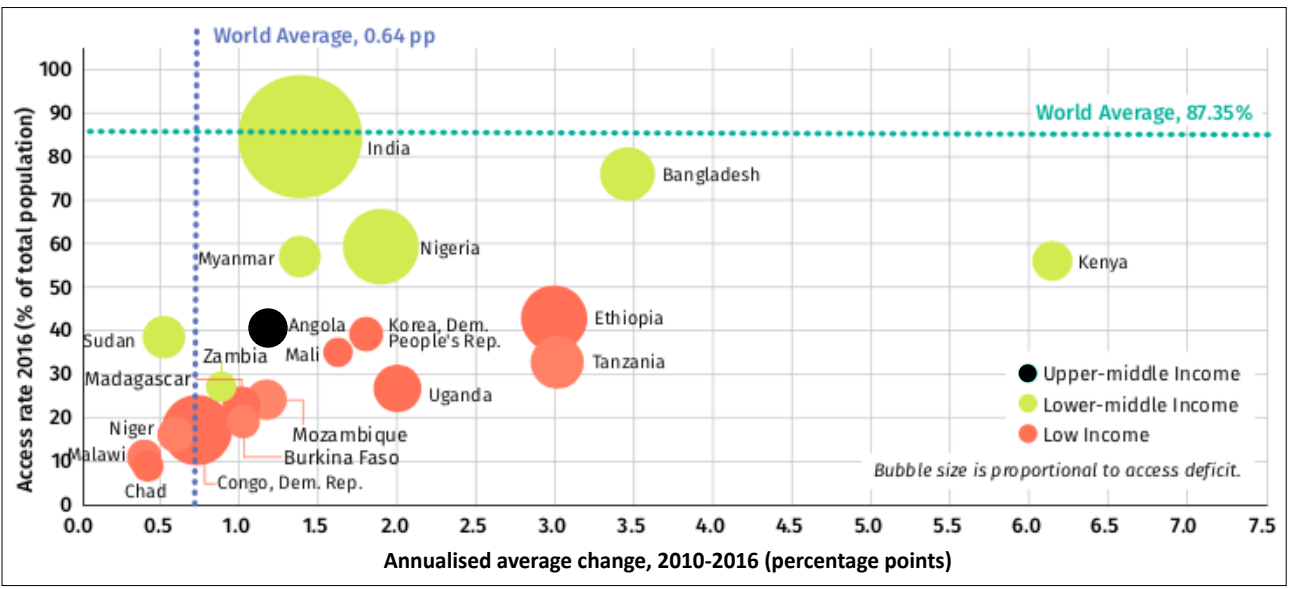

Figure 3.1 The 20 countries with the largest electricity access-deficit over the 2010-2016 period (Source: World Bank, 2018:23)

The UN Sustainable Development Goal 7 (SDG7) focuses on a concerted global effort to ensure access to affordable, reliable, sustainable and modern energy for all. The other 'branches' of SDG7, namely, improvements in efficiency and increased implementation of renewables have also seen progress. Energy efficiency also continues to improve, driven by advances in the industrial sector and household appliances, which could have transformative results in doing more with less. Growth in renewable energy expansion across Africa also made gains in the electricity sector in both grid-based and off-grid systems, though much of this growth is concentrated in a handful of eastern and southern African countries. However, despite the huge attention on Africa from potential investors as a new clean energy frontier, the region is still struggling to shed the perception of being high-risk area for energy investment as well as the fact that the utility infrastructure necessary for large-scale renewable power plants is not fit for purpose in many African countries.

Beyond electricity, solid biomass - including wood, charcoal, animal dung and crop waste - is the primary cooking and heating energy source for nearly 730 million 
people in sub-Saharan Africa. The high level of reliance on traditional use of solid biomass, typically with inefficient stoves in poorly ventilated space, imposes immense health, environmental and social costs for households. Currently, over 600000 women and children die annually from indoor air pollution associated with the use of firewood for cooking (APP, 2015). Furthermore, energy production from unsustainable biomass harvesting in Africa as fuelwood and for charcoal production is significant. This exacerbates the strains on the forestry stock and contributes to rises in greenhouse gas (GHG) emissions (Bruckner et al., 2014). A transition to cleaner cooking fuels and appliances faces numerous obstacles, not least because people who have access to modern fuels, such as low-pressure gas, natural gas, biogas or electricity, may also continue to use solid biomass for cultural, cooking or cost reasons - a phenomenon known as 'fuel stacking'.

\section{Theorising Africa's sustainable energy system, innovation and development}

During the early post-independence years, the conventional development narrative described the continent as a new frontier of Western-style economic growth based on agricultural modernisation and expansion of the manufacturing sector, powered by large-scale power plants reliant on a mix of fossil and large hydro fuels. The model promised that such energy investments would drive the creation of highquality jobs, increase incomes, and facilitate access to education, health, and other benefits consistent with a relentless economic growth agenda. The 'Conventional energy systems' column of Table 3.1 summarises some of the key components of the paradigm that, as noted earlier, has governed post-independence African energy initiatives. Amory Lovins provides a detailed critique of such systems, referring to the collection of policy, market and technology choices as constituents of a 'hard energy path' (Lovins, 1977). A recurring fact about the energy-development history of Africa features a succession of large-scale energy projects bearing the unmistakable stamp of hard energy 'cookie cutters.'

Having been swayed to accept for decades by the premises and promises of hard energy path advocates and technocrats, African governments and their development partners today find themselves caught in a cycle of continually allocating disproportionate shares of national resources for energy and other infrastructure projects serving the minority in urban centres. Rather than build needs-oriented energy solutions for all, governments and their development partners have not been able to think outside the box of centralised and complex energy systems. Years of institutionalised, elite-led energy planning and policy have produced not the benedictions of universal energy access but the maledictions of deepening energy poverty and inequity. 
Table 3.1 Conventional versus sustainable energy systems

\begin{tabular}{|c|c|}
\hline Conventional energy systems & Sustainable energy systems \\
\hline \multicolumn{2}{|c|}{ Energy policy } \\
\hline $\begin{array}{l}\text { Fossil, large-hydro, nuclear promotion } \\
\text { Production incentives } \\
\text { Reliability-focused regulation } \\
\text { Removal of most market barriers } \\
\text { Expansion of demand } \\
\text { Local adaptation to national choices } \\
\text { Standardisation of delivery systems }\end{array}$ & $\begin{array}{l}\text { Renewables dominant } \\
\text { Efficiency incentives } \\
\text { Focused on end-use regulation } \\
\text { Creation of efficiency institutions } \\
\text { Expansion of end-use efficiency } \\
\text { Local choices and responsibility } \\
\text { Diversification of delivery systems }\end{array}$ \\
\hline \multicolumn{2}{|c|}{ Energy market } \\
\hline $\begin{array}{l}\text { Supply-oriented } \\
\text { Capital-intensive investment pattern } \\
\text { Fuel-based prices } \\
\text { Emphasis on near-term costing } \\
\text { Supply-demand balance of quantity } \\
\text { Fuel competition } \\
\text { Maximisation of consumption }\end{array}$ & $\begin{array}{l}\text { Efficiency oriented } \\
\text { Diversified capital investment pattern } \\
\text { Social/environmental cost-based prices } \\
\text { Emphasis on life-cycle costing } \\
\text { Supply-demand balance of services } \\
\text { End-use competition } \\
\text { Maximisation of conservation }\end{array}$ \\
\hline \multicolumn{2}{|c|}{ Energy technology } \\
\hline $\begin{array}{l}\text { Large-scale/technology intensive } \\
\text { Central/interconnected systems } \\
\text { Industry-driven technology choice } \\
\text { Limited technology options } \\
\text { Production/economic cost-based }\end{array}$ & $\begin{array}{l}\text { Small-to-moderate scale dominant } \\
\text { Decentralised/locally responsive } \\
\text { User-driven technology choice } \\
\text { Diverse technology options } \\
\text { Social/environmental costs-based }\end{array}$ \\
\hline
\end{tabular}

(Source: Adapted from Wang, 2001:3)

A radically different story of energy challenges and prospects in Africa has gained traction in recent years. Far from perceiving the unserved hinterlands of the continent as virgin territory ready for fossil-powered corporate profit-maximising energisation, the new narrative tells the truth about impoverished landscapes of unmet needs, lost human freedoms and the progressive decline in capacities to seize opportunities - the underbelly of failed national energy regimes. New and more accurate analyses are exposing the scourge of energy poverty, inequality and injustice beyond affluent urban enclaves - a world beyond the grid, inhabited by millions of people living in rural settlements with the lowest per capita use of electricity in the world. People in such areas rely heavily on inefficient biomass converters as their main source of household energy for cooking and other basic services. The multi-dimensional scope of the new narrative captures the deprivations suffered by Africa's energy-poor, such as unreliable communication systems, weak or non-existent transport infrastructure, and inadequate educational and health systems, especially for women and children. Studies by scholarpractitioners associated with a 'bottom-up' energy planning school of thought are providing a clearer picture of persistently low levels of productivity in primary, secondary and tertiary sectors; the anaemic livelihood systems; and the erosion of income and wealth-creating opportunities (Practical Action, 2010). Inadequate 
energy access - itself a function of severe deficits in knowledge, financing, enabling institutions and policies - is at the root of these negative development outcomes of the hard energy path.

These conditions have accelerated the emergence over the past several decades of novel schools of thought around an alternative paradigm of energy for sustainable development. At its most general, the new framework 'emphasises the process of changing the interlocking nature of energy, economy, environment and equity (E4) to conform with sustainability' (Wang, 2001:2. Branching out from the 'seed' idea of sustainable development (World Commission on Environment and Development [WCED], 1987) the major strands of this emergent paradigm include 'soft energy paths (Lovins, 1977), Pezzey's proposition that sustainability be understood as being distinct from optimality and survivability (Pezzey, 1992), and Daly's definition of 'development' as a transformation that makes something qualitatively better, not simply bigger in size (Daly, 1993). From this standpoint, a sustainable energy system is not merely designed to drive economic growth and quantitative proxies of quality of life improvements. Rather, it aims to transform and re-orient the E4 relations in ways that increase wellbeing within the regenerative and assimilative capacities of the environment. As illustrated in Figure 3.2, the strong interplay amongst the elements making up $\mathrm{E} 4$ can gather momentum over time to produce higher levels of wellbeing in a manner that these interactions can become self-organising and self-reinforcing. Of course, in order for the multiple benefits to be felt, policies would need to be integrated, and sectoral boundaries loosened. The sustain energy model thus entails properties and 'rules of the game' that have little, if anything, in common with those of the conventional (hard) energy paradigm (see the 'Sustainable energy systems' column of Table 3.1).

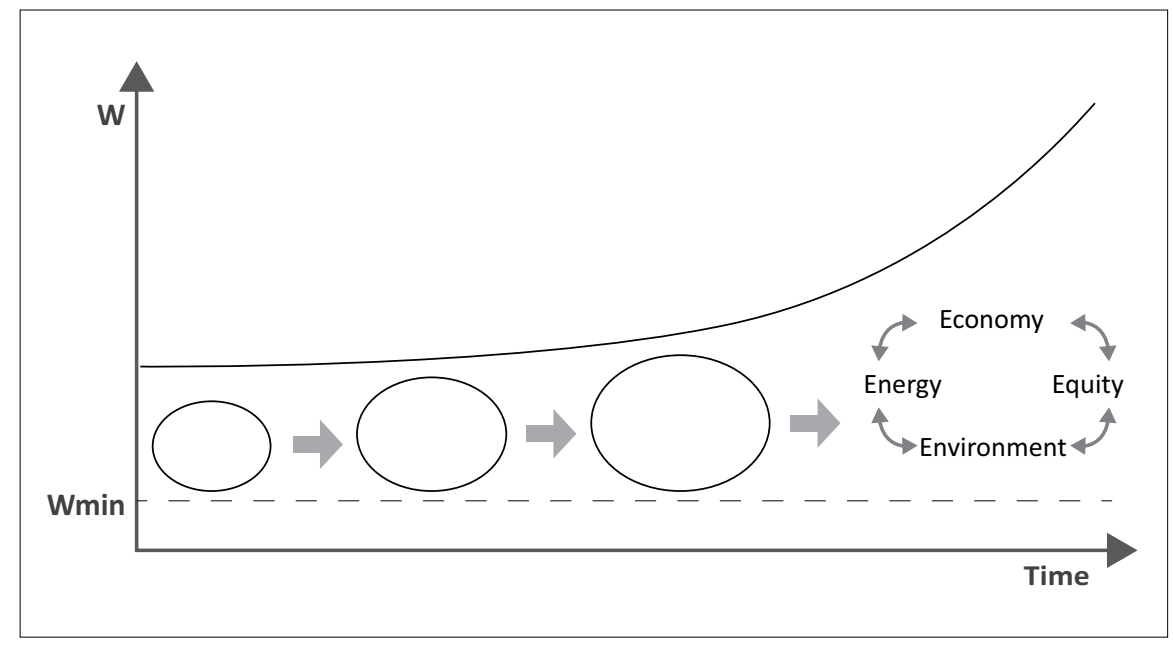

Figure 3.2 E4-Wellbeing relations (Source: Wang, 2001:2) 
As part of the newly invigorated discourse on energy-development relations in Africa, attention has largely shifted from theoretical endeavours aimed at defining sustainable energy systems to action-oriented efforts seeking to operationalise the concepts in specific contexts. There is a growing consensus that however it might be defined, the common denominator of any sustainable energy transition agenda is to respect fundamental truths, principles, criteria and indicators that are different from the governing conventions of the day. Energy system transformation processes should diverge from the current unsustainable path. The time to operationalise a transition agenda is now.

A recent contribution to the energy transition literature is the Energy Transition Index (ETI), an empirical tool for measuring energy system performance and thereby 'identify imperatives and align policy and market enablers accordingly' (World Economic Forum [WEF], 2019. It emphasises the importance of simultaneously pursuing an energy transition on three broad variables, namely: Access and Security, Economic Development, and Environmental Sustainability (WEF, 2019). The ETI thus offers a flexible framework for elaborating contextsensitive criteria to guide transition strategy and policy in Africa. However, when we consider Africa's historical experience with authoritarian energy regimes, it becomes obvious that the ETI is missing a critical variable - freedom. This point of view is well supported by Armatya Sen's seminal theory of 'development-asfreedom' (Sen, 2000).

The ETI has also been used to evaluate an economy's readiness to implement the necessary conditions for a sustainability transition. Transition management theory suggests that an important measure of readiness be defined by the capacity of 'societal networks of innovation' to generate 'sustainability visions' based on which transition paths and a common transition agenda may be drawn up to guide planning and policy (Kemp \& Loorbach, 2006). Loorbach (2010) has defined such networks as 'transition arenas' comprising small networks of frontrunners who, among other capabilities: (i) are able to consider complex problems at a high level of abstraction, (ii) are transdisciplinary thinkers, (iii) enjoy a level of authority within various network, (iv) are skilled communicators in explaining visions of sustainable energy and development to key stakeholders, (v) are willing to engage in group thought processes, and (vi) are open to innovative thoughts and solutions other than what they might have in mind.

Although particulars will vary according to context, it is difficult to exclude the following as the key arenas of interacting frontrunners in any assessment of an African country's energy transition readiness: (i) energy-system structure transformation, (ii) building political commitment (regulatory policies), (iii) stimulating capital and impact investment, (iv) establishing enabling institutions and governance, 
(v) mobilising human capital and stakeholder participation, and (vi) innovation system and infrastructure build-up.

Development of this framework is continuing to benefit from applied policy research and country case studies of multi-level transition management. There is an emerging strand of ideas from system innovation studies including the notion of inclusive innovation (Falcone, 2014; Foster \& Heeks, 2015; Geels, 2005; Geels et al., 2016; Raven, Van den Bosch \& Weterings, 2010). Attempts to apply these concepts in studies of green industrialisation in Africa have appeared in the literature (Okereke et al., 2019).

While casting much-needed light on energy realities beyond the purview of the conventional narrative, the sustainable energy paradigm also presents a more optimistic view of Africa's energy future as well as practical ways of getting there. Highlighted already in the introduction of this chapter, some of these include: (i) the rising demand for energy, creating investment opportunities; (ii) a rapidly growing domestic economic wealth that is yet to be unlocked for energy investment; (iii) Africa's significant primary energy resources, especially in renewable energy resources, raising the attention of investors for both domestic demand and export, even beyond the region; and (iv) the rapid reduction in the cost of renewables, making them competitive against conventional fossil fuels and also increasing the viability of off-grid systems to meet energy needs in rural areas.

\section{The energy, climate and development dilemma in Africa}

Today, discussions about energy often take place in the shadows of climate change and development discourses. Scarcely a day passes without climate change being raised as an issue in energy policy debates. Sometimes the concern is with the implications of rising GHG emissions from fossil fuel on human and ecosystems or future generations. Sometimes it is directed at the financial cost of certain decarbonisation actions in energy development and who should pay or of innovations that lead to desirable outcomes. Other times, it is about what happens to economies under conditions of deep decarbonisation (e.g., oil producers) or how lifestyles would need to change to ensure consumption levels are under control to avoid punching through the $2^{\circ} \mathrm{C}$ or the $1.5^{\circ} \mathrm{C}$ ceiling (Mulugetta \& CastanBroto, 2018). In this regard, policymakers across Africa now recognise that while Africa's historic responsibility for current climate change is minimal (2-3 percent GHG and 18 percent population), this position takes a static perspective about Africa and assumes that the continent will remain too poor to take up a higher share of the global GHG footprint. Africa's energy demands are increasing, and its energy mix is changing, but there is still plenty of headroom for managing the transition given that the region's energy system is yet to be built, and decisions made 
today will have repercussions for many years to come. This section explores the connections between climate change and Africa's energy system and sketches out the opportunities for investment that would help to upgrade energy infrastructures.

\section{Equity considerations are crucial}

The Paris Agreement confirmed the need to strengthen the global response to keep a global temperature rise this century well below $2^{\circ} \mathrm{C}$ above pre-industrial levels, and pursue efforts to limit the temperature increase to $1.5^{\circ} \mathrm{C}$. According to the United Nations Framework Convention on Climate Change (UNFCCC), the voluntary pledges in nationally determined contributions are currently tracking toward a warming of $3-4^{\circ} \mathrm{C}$ above pre-industrial temperatures (UNFCCC, 2016). Without a profound transformation of economic and of energy systems at all levels, the current efforts are not sufficient to keep temperature changes under safe levels. The transformations required for deep decarbonisation may also have cobenefits for energy poverty and improving energy access, and hence, they could have a direct impact on enhancing wellbeing and livelihoods in many countries (Ribera et al., 2015). The need for a realignment of current systems of production and consumption within ecological limits is also endorsed by the SDGs at the $\mathrm{UN}$, emphasising the importance of 'access to affordable, reliable, sustainable and modern energy for all', and the recognition that none of the other SDGs can be achieved without adequate access to energy services. That access to modern energy services has gained ever greater attention globally in recent years partly reflects its critical importance to all three pillars of sustainable development.

While the need for decarbonisation is essential for addressing climate challenges, there is a disjuncture between responsibility and consequence in the way the costs and benefits of climate actions are distributed across space and social groups. Questions of justice and fairness are central to the issue of climate change and response efforts across geographies and generations. Several authors outline four key points of connection between climate change and justice from the international regime (UNFCCC) perspective (Harlan et al., 2015; Okereke, 2010; Shue, 2013). This issue was covered well in the latest IPCC report on the $1.5^{\circ} \mathrm{C}$ warming (Allen et al., 2018). The first is the huge asymmetry in contributions to the problem of climate change in that the benefits of progress and development have been unevenly distributed and those who have benefited the most historically have contributed the most to the climate challenge. The second is the asymmetry in facing the impact of climate change - a problem which is exacerbated because the worst impact tends to be felt most by people and communities least responsible for the problem. The third is the asymmetry in power to decide solutions and response strategies in that the more powerful actors can use their greater influence to 
define positions and agendas that suit them. Fourth is an asymmetry in the capacity of future-response whereby some states and places are at risk of being locked out in terms of solutions as the world progresses to a low-carbon economy (Fleurbaey et al., 2014; Humphreys, 2017).

In this context, it is worth asking what are the justice implications for Africa in either volunteering or being pressured to take a low-carbon development route? Arguably, investments in low-carbon technologies offer some opportunities to tackle poverty while increasing mitigating or adapting to climate change. A classic example is the distributed renewable energies for off-grid communities, which in addition to being climate-friendly can increase socio-economic development and enhance adaptive capacity (Sokona et al., 2012). However, it is also possible that some low-carbon pathways may require more upfront investment than conventional pathways, and so there may be complex trade-offs between cost per unit of energy, biodiversity loss, climate change and localised air pollution (Fuso-Nerini et al., 2018). Equally, it is important to recognise that realising greater welfare and wellbeing cannot be achieved without peaceful societies and equal access to justice (SDG16).

In relation to the above, placing the climate discussion in its historical (and political) context has two important functions. Firstly, it helps us to appreciate the genesis of the problem and the possible effect of global warming on present and future generations, hence situating local impacts firmly into global politics and economics, as well as discussing inequality in a concrete way. Secondly, history helps us to explain the evolution of social and environmental systems, with explicit consideration of relations of power thereby providing the platform to challenge 'dominant accounts of environmental change' (Robbins, 2004:12). The argument here is that environmental change and ecological conditions are fundamentally tied to larger issues of economic, social and political processes within which the 'triple inequality' of vulnerability, responsibility and mitigation are embedded (Roberts \& Parks, 2006).

\section{Energy and climate dilemma}

Globally, the key issue in energy and sustainable development is climate change. However, countries in Africa have very low $\mathrm{CO}_{2}$ emissions from electricity generation and industrial fossil-fuel use. They account for 42 of the 50 countries with the lowest such emissions in per capita terms in 2014, with median per capita emissions less than one-fiftieth of some developed countries and major oil exporters (Boden, Andres \& Marland, 2017). Leaving aside South Africa and the North Africa region, emissions are low across Africa, mainly because economic activities are lower than other regions, and much of the population still lacks adequate and clean energy services (Pachauri et al., 2013). According to the World Resources Institute 
(WRI), Africa's per capita emissions of $\mathrm{CO}_{2}$ amounts to about 2.7 to 3.9 tonnes per person $\left(\mathrm{tCO}_{2} / \mathrm{pp}\right)$ per year depending on whether land-use change and forestry are included in the calculations (WRI, 2014). Still, these figures compare favourably against an annual Asian average of about 5-5.3 $\mathrm{tCO}_{2} / \mathrm{pp}, 9.7-10.3 \mathrm{tCO}_{2} / \mathrm{pp}$ for Europe and over $20 \mathrm{tCO}_{2} / \mathrm{pp}$ for North America. To limit global temperatures to $2^{\circ} \mathrm{C}$, the atmospheric concentration must not exceed $450 \mathrm{ppm}$ (parts/million) $\mathrm{CO}_{2}$ equivalent (IPCC, 2013). This means the annual average per capita emissions will need to converge at $2.1-2.6 \mathrm{tCO}_{2} / \mathrm{pp}$, and of course, staying within the $1.5^{\circ} \mathrm{C}$ global temperature limit means an even smaller 'carbon budget' to play with.

Three key trends are likely to change this picture. Firstly, Africa's population is growing significantly and is estimated to amount to 25 percent of the global population by 2100 (United Nations Department of Economic and Social Affairs [UNDESA], 2015). Secondly, Africa has the fastest-growing urban population, driven by internal growth and migration from rural areas, and often cities tend to be associated with higher levels of per capita consumption of energy. Thirdly, the economies of Africa have plenty of headroom to grow, which will require more energy to sustain growth. In short, the African emissions will rise in aggregate, and Africa's share in global energy-related $\mathrm{CO}_{2}$ emissions is projected to increase markedly. The only questions are the size of this increase and which regions, or countries will experience concentrated growth. The answers to the questions depend on the development pathways countries choose or compelled to pursue. According to Lucas et al. (2015) without a climate policy that is underpinned by a robust strategy for sustainable energy, this increase in demand for energy services will most likely be supplied by fossil energy sources, which will mean that Africa's energy-related $\mathrm{CO}_{2}$ emissions are expected to increase by a factor 7 to 50 between 2010 and 2100.

Whilst action concerning climate adaptation is critical for Africa, it is equally important to implement mitigation efforts to avoid a high carbon lock-in that other countries had experienced in their development journey. Furthermore, actions, such as the widespread adoption of renewable energy in power generation and cooking, would bring multiple benefits in health, education and energy security. According to the IEA (2014), the total consumption of biomass in sub-Saharan Africa burned directly and to produce charcoal amounted to 658 million tonnes in 2012. The region also represents the world's highest regional per capita wood energy consumption, amounting to an average consumption of $0.69 \mathrm{~m}^{3}$ per year (or 1.66 tonnes/year) in 2011 , compared to a global average of $0.27 \mathrm{~m}^{3}$ or 0.65 tonnes per year (Iiyama et al., 2014). This demonstrates the dependence on biomass for household energy but may also indicate that the unsustainable harvesting of biomass (although there are large geographic variations) exists. For example, Bailis, 
Drigo, Ghilardi and Masera (2015) estimate that 27 to 34 percent of woodfuel harvested across the developing world is unsustainable, which contributes to the concentration of woodfuel depletion 'hotspots' in South Asia and East Africa. Hence, it would appear that large efficiency gains can be achieved along the entire woodfuel and charcoal value chain, helping to reduce GHG emissions significantly.

Industry accounted for half of the electricity consumption, with services using about 20 percent, and the rest distributed across household energy and agriculture (Hogart, Haywood \& Whitley, 2015). Most power systems in Africa experience major challenges associated with power outages, which has a major knock-on effect on the economy and performance of health and education systems. In terms of GHG emissions, the power sector accounted for about 63 million $\mathrm{tCO}_{2} \mathrm{eq}$, about 2 percent of the region's total GHG emissions. This seemingly low share of the total indicates the low consumption of electricity on a per capita basis; and the low levels of access to electricity in several countries.

To illustrate the $\mathrm{CO}_{2}$ emissions embedded in the electricity supply system of some individual countries and the regional power pool systems, a rough Grid Emission Factor (GEF) was assembled using data provided by the International Renewable Energy Agency (IRENA) to illustrate (see Figure 3.3) over the 2015-2025 period. To serve for comparison purposes, Figure 3.3 also consists of national GEF from a range of countries from the region and other regions. The GEF serves to quantify the amount of carbon dioxide (equivalent) emissions associated with each unit of electricity from different sources of power generation fed into the grid and provides a single figure reflecting the composite carbon value.

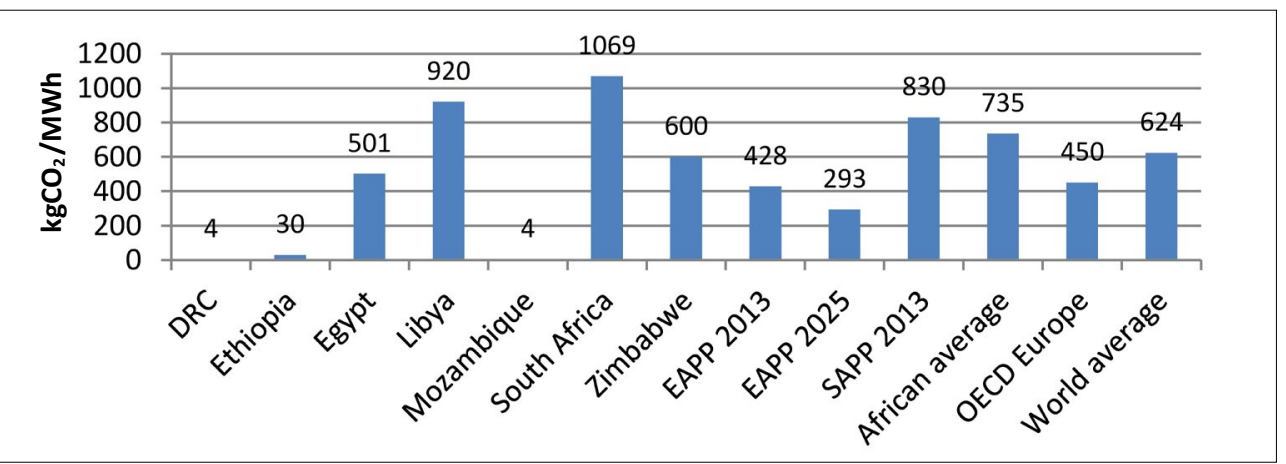

Figure 3.3 Grid Emission Factor for various electricity generation systems (Source: Calculated from IRENA data in Brander, Sood, Wylie, Haughton and Lovel, 2011:4-6)

Figure 3.3 also shows the range of decarbonisation opportunities and challenges that countries and power pools will face. Several East African countries show considerable room for the development of low-carbon energy systems through a 
variety of renewable energy and low-emissions options, which is also reflected in the GEF for the East African Power Pool (EAPP). The story for the southern and northern African regions is different. The transition from fossil-based power system is not as straightforward since there is a considerable sunk cost in fossil-based power systems that would need to be phased out as part of the decarbonisation pathway. In the future, these two regions offer the largest decarbonisation potential in terms of reduction of carbon intensity per unit energy as a result of a comprehensive strategy of energy efficiency and renewable energy developments. Specifically looking at South Africa, one of the major climate change mitigation issues it faces is the need to reduce GHG emissions from the power sector, primarily reducing its heavy dependence on coal.

As governments across the region are looking at their progress in reducing their emissions, their interventions would need to be compatible with local developments and people's aspirations regarding their wellbeing. This means that energy systems would need to be integrated into the fabric of local economies and embrace radical notions of modernity. The SDGs offer a useful framework for integrating energy across the range of goals, thereby identifying potential energy interventions that have multiple benefits.

\section{Distributed energy as a sustainable energy pathway}

The past few years have seen the coming of age of distributed generation and smart energy systems. There are a number of characteristics that smaller and locally embedded systems bring to local development in Africa, for example, unlike traditional centralised systems, these locally embedded systems can be tailored to local contexts in terms of household needs and socio-economic circumstances. As such, a more diversified ownership base can be implemented. This base involves large number of households, communities, cooperatives, smalland medium-sized enterprises, as well as larger companies, which become both producers and consumers of electricity. This could allow small and locally-based systems to become innovators of grassroots systems where social learning and experimentation can take place, creating the evidence for scaling up. This section will explore a variety of cases and innovations where bottom-up energy systems have been deployed to address concrete needs.

The section will explore questions concerning the efficiency of resource use, social justice as well as economic resilience, and the role that needs-focused systems can contribute towards such goals. 


\section{Synergies between access, energy efficiency and renewable energy}

Depending on population density and income levels, in many parts of the world it is cost-effective to extend the grid where the distance to the transmission and distribution $(T \& D)$ lines is within a specific range. This range usually includes urban and peri-urban areas where human settlement is of sufficient density to justify the infrastructure cost. However, this condition does not apply to many rural areas. Indeed, human settlement across Africa is highly dispersed, which has contributed to a limited dispersion of T\&D grids. The current pattern of sparse settlements, coupled with low per capita energy consumption levels, at $590 \mathrm{kWh}$ in 2012 compared to the world average of $2970 \mathrm{kWh} /$ capita, make it costly to extend the grid to most households in the foreseeable future. Power utilities have lacked the finance to improve the situation, while most people have had too little money to pay for connections and the electricity that they would consume. This does not only apply to households, but also to enterprises in rural areas that continue to operate their productive activities at low energy throughput or are heavily constrained by the poor reliability of incumbent energy systems. In recent years, the emergence of new technologies and the lowering of their cost has made it possible for distributed renewable energy systems to be considered as viable alternatives in terms of cost, convenience, speed and impact on the natural environment. This section discusses the various benefits and costs associated with distributed energy production, distribution and use in Africa as critical for meeting sustainability goals. Three important points justify the distributed energy thesis.

Firstly, as discussed in earlier parts of this chapter, widening energy access to modern energy for rural transformation has been gaining momentum over the past ten years, and is now seen as crucial to meeting many of the SDGs (FusoNerini et al., 2018). Almost all development partners now have an energy access programme of some nature, and most countries across Africa have universal access to modern energy targets.

Secondly, energy efficiency is now seen as an increasingly important consideration in delivering modern and affordable energy services. Improvements in efficiency can be considered an additional resource, and so there are benefits in making improvements in demand-side efficiency as well as minimising transmission and distribution losses for investments in renewables to deliver higher impact for each unit investment. A sustainable energy economy requires major commitments to energy efficiency before looking at investing in renewable energy development.

Thirdly, as renewable energy continues to gather momentum, more renewables are being accommodated in the grid, and off-grid using renewables are becoming 
cost-effective and reliable options for electrifying rural areas. The flexibility they offer in terms of their modularity makes renewables ideal for tailoring to specific end-use situations. Innovations that lead to cost reductions in storage systems will make them even more attractive than fossil-fuel alternatives in the future.

Looking closely at the off-grid options, stand-alone renewable energy (RE) home systems are simpler to deploy than mini-grids and have been deployed successfully in large numbers with support from governments and donors and governments. There are over 500000 solar home systems (SHS) across Africa, mostly in East Africa and South Africa (IRENA, 2015). Although there has been an upward trend in recent years, the off-grid SHS market is still quite small compared to other regions. For example, Bangladesh has significantly more SHS than the whole of Africa. As of 2016, over 4 million SHS had been installed, due to a very successful, long-running implementation programme impacting more than 12 percent of the population in Bangladesh (IRENA, 2016). The pico-scale solar product is another stand-alone system that has made a significant impact on the African energy landscape. This system addresses lighting and small load end-uses and is driven by an increasing number of private firms on a commercial basis (Nygard, Hansen \& Larsen, 2016).

The pico and SHS systems have been hugely beneficial for households and businesses in addressing their lighting needs. However, they support limited services and are not suitable for multiple appliances, especially those with higher wattage, such as refrigerators. In the off-grid category, mini-grids are being increasingly used to supporting larger loads and higher load variance and these systems meet the needs of over 5 million people worldwide (IRENA, 2015). Mini-grids offer considerable advantages over both grid-based and stand-alone systems where grid extension is not economically attractive but where communities live in a core village with houses nearby (see Figure 3.4). This avoids the cost of transmission infrastructure, which can amount to a significant share of the total electricity bill of a power system. According to Bardouille et al. (2012), the average capital cost for providing a new connection to a household with a mini-grid starts at $\$ 50$, whereas the cost of providing a new connection by extending the main grid to a household that is sufficiently close to it can start at $\$ 500$. New connection charges in sub-Saharan Africa are among the highest in the world, resulting in low rates of electrification in many countries. Smaller independent grids offer more practical alternatives in many rural situations, and if operated well, they can scale up and become attractive for connecting with the main grid as the local economy grows (Mitra \& Buluswar, 2015). There are plenty of such experiences across Europe and North America. 


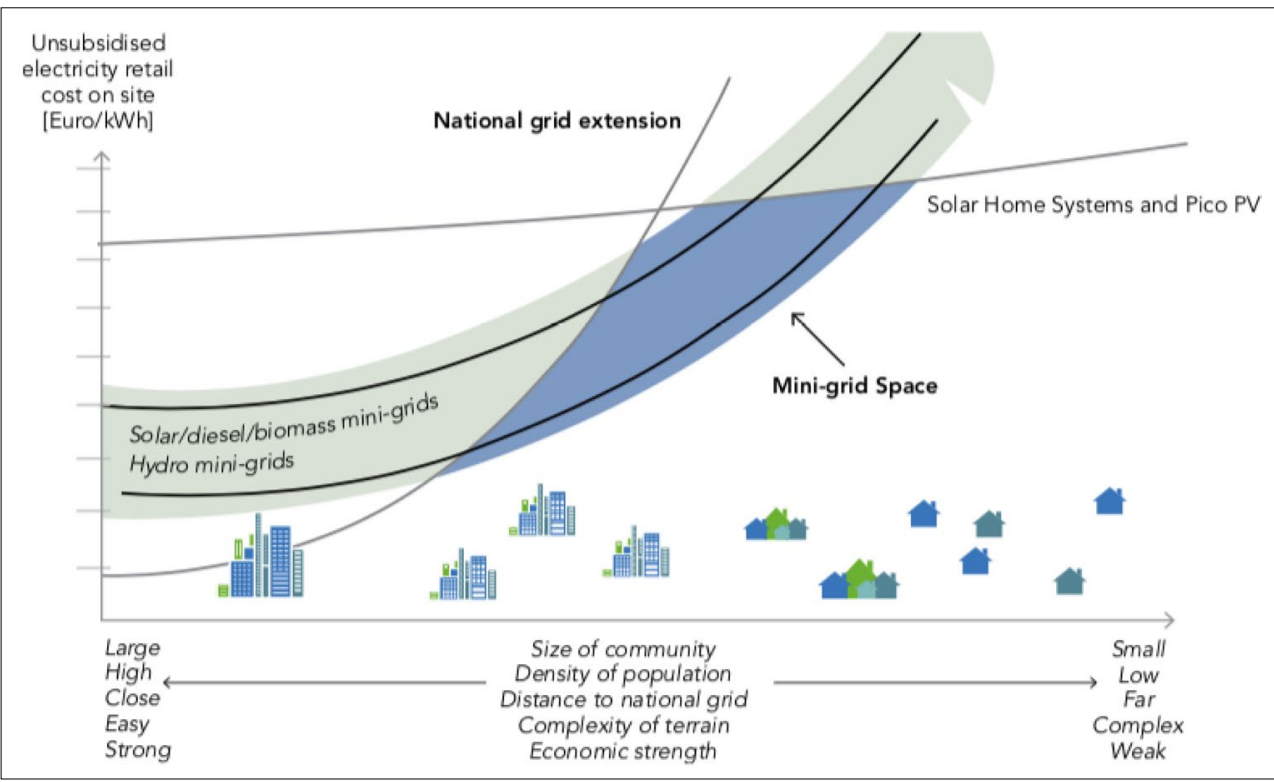

Figure 3.4 The role of mini-grids in an electrification programme

(Source: Franz, Peterschmidt, Rohrer and Kondev, 2014:20)

Mini-grids offer more transformational potential than stand-alone systems and other advantages over grid systems, however they, these systems face significant technical, economic and institutional barriers. They involve large up-front costs, tariffs that are often higher than those charges to on-grid consumers, and they need on board site-specific conditions on resources and institutional arrangements (Least Developed Countries Renewable Energy and Energy Efficiency Initiative [LDC REEEI], 2018). This is especially important for countries in Africa where the institutional concerns around cost calculations, ${ }^{1}$ regulatory uncertainties, potential conflict among actors and operation and maintenance arrangements could create major obstacles due to the limited experience in the development of mini-grids.

The key is that careful planning and a forward-looking approach to widening electricity access wherein mini-grids can be integrated into local livelihoods and economies is important. This would need those involved to deal with the potential complementarity of grid and off-grid solutions where in the event the grid reaches the mini-grid service area, policies and agreements are in place to transform the mini-grids into distribution utilities. Such forward planning would give investors' confidence to develop mini-grids in rural and remote areas, knowing

1 Cost calculation of mini-grids tend to be more complicated. Unlike the entrepreneurial drive that stimulates the growth of stand-alone systems and highly institutionalised top-down pricing of grid-based systems, cost calculations of mini-grids depend on technology and geographical location and require more planning and institutional development. 
that their investment will be compensated or allowed to convert their operation into an interconnected mini-grid 'when the big grid connects with the small grid' (Tenenbaum, Greacen, Siyambalapitiya \& Knuckles, 2014).

Some African countries, such as Nigeria, Rwanda and Tanzania, have developed rules or regulations that allow mini-grids to become small power distributors or sell exclusively to the grid, along with compensation rules should they wish to exit the mini-grid business. It is too early to say whether these regulatory rules will be implemented or not. Experience from Asia, especially from Cambodia, has been quite impressive where the country's regulatory and subsidy policies enabled hundreds of privately-owned diesel mini-grids to make the transition toward gridconnected small power distributors. According to the World Bank (2017a), the conversion has allowed private operators to provide their customers with longer hours of service at significantly lower prices - a good sign that mini-grids have come of age.

\section{Needs-based planning: From household to community energy}

The chapter has highlighted that the energy system in sub-Saharan African countries is inherently complex given its dual nature where the traditional and modern energy systems and practices co-exist (Sokona et al., 2012). The provision of services through centralised and interconnected infrastructures has its place, particularly in the more densely settled urban areas. However, there are large parts of countries, often rural and remote, where this approach/model has failed to deliver basic services such as sanitation, water and energy services to communities. The high dispersal of settlement patterns, the rapid reduction in the cost of renewables, and the new policy and regulatory attention devoted to the energy access agenda creates ideal conditions for off-grid energy systems to meet local development needs in Africa.

Policymakers also recognise that 'failing to plan is planning to fail', and so planning the future direction of the energy system needs to embrace all options and scales (Mulugetta, Ben Hagen \& Kammen, 2019). Often those engaged in energy planning start with numbers - numbers of people without access to modern energy, the proportion of people who rely on electricity from renewables or the cost of per unit electricity. This is then followed by the importance of bringing electricity or some other fuel to meet needs. This somewhat linear construction is often at odds with a needs-based approach focused on determining citizens' needs, and planning based on people's lived experiences, needs and aspirations. Over the years, several researchers have recommended a bottom-up approach to planning where users are placed at the heart of the decisions on technology options for planning to be accountable and representative (Goldemberg, Johansson, Reddy \& Williams, 1985; Hiremath, Shikha \& Ravindranath, 2007). 
Following the long tradition of rural energy planning that emerged following the oil crisis of 1970s, organisations such as Practical Action have been developing bottom-up energy planning approaches for over a decade. Their total energy access (TEA) approach, built on the back of several decades of field experience, helps communities to identify the combination of energy access technologies that address development and poverty goals (Practical Action, 2016).

The TEA approach encompasses:

all spheres of energy access: households, productive uses and community facilities, differentiated by gender;

all forms of energy access: electricity, cooking, heating and mechanical power; and

all feasible and appropriate means of energy provision: grid-connected, minigrid, and stand-alone.

The World Resources Institute (WRI) proposes another bottom-up approach, known as 'bottom-up demand forecasting' (Odarno, Sawe, Swai, Katyega \& Lee, 2017). Like the TEA approach, this approach is complementary to the SE4ALL's ${ }^{2}$ Multi-tier Framework for electricity access as it focuses on different levels of access based on differentiated energy needs. Access at different tiers can be satisfied by numerous options, and the tiers can vary over time and space. For instance, some remote rural communities need only lower-tier levels of electricity service in the early stages of access and development. This means that bottom-up demand forecasting approach will need to take account of changing consumption patterns over time; and may be survey-based or may be derived from end-use models. The end-use model quantifies electricity demand based on the consumers' current and projected electricity end-use patterns (Dharmadhikary \& Bhalerao, 2015).

Such bottom-up concepts work on the premise that the future energy systems across Africa will be increasingly diversified and distributed, with increasing numbers of actors as energy producers who will meet their own needs. In some cases, they may engage in selling their surplus to other users and import electricity when needed. With their flexibility, modularity and scalability, smaller distributed projects can be initiated simultaneously with significantly reduced construction

2 The UN's Sustainable Energy for All (SE4ALL) initiative was launched in 2012. This initiative aims to improve the lives of the poorest and most vulnerable people by ensuring universal access to modern energy services, increasing the share of renewable energy sources around the world, and improving energy' (International Institute for Environment and Development [IIED], 2012). 
times compared to large centralised installations (LDC REEEI, 2018). Given the urgency for action in Africa, such systems are vital in providing electrical and nonelectrified systems to provide lighting, heating, cooling, transportation and other needs locally.

Estimations of demand based on end-use data enables planners and service providers to seriously think about energy efficiency and demand-side management as it can lead to a reduction in cost by doing more with less energy. Efforts in energy efficiency need to happen at the supply side as well as the demand side. According to IEA (2014), transmission and distribution losses in sub-Saharan Africa average about 18 percent with some countries recording over 20 percent losses. This transfers considerable resources that could otherwise be reinvested in the country's critical infrastructures. On the supply side, part of the strategy to reduce such transmission and distribution losses would also include having a good mix of on-grid and off-grid systems. On the demand side, the focus is on reducing the overall electricity demand of consumers (end-users) by introducing highefficiency appliances and raising awareness about the value of energy conservation. For the off-grid contexts, demand-side efficiency improvements have been crucial in bringing down the overall cost of stand-alone and mini-grids.

\section{Typologies of distributed rural energy in Africa}

There is a wide range of business models in both the grid-based and off-grid systems. It would be beyond the scope of this chapter to explore all. Instead, given the interest of this chapter in distributed energy for local development, this chapter focuses on the business models that relate to stand-alone and mini-grids.

Although mini-grids have a long history electrifying rural villages, standalone systems are now far more common, especially in Africa. According to IRENA (2018), about 133 million people accessed lighting and other electricity-based services using off-grid renewables in 2016; mostly using pico lighting and solar home systems, and about 9 million are connected to a mini-grid. As shown in Table 3.2, to an extent these off-grid variants are competing for the same rural electrification market, albeit to power different devices, and the growth of one will have implications on the other. For example, investment in mini-grids may seem to be too risky in areas where small-scale renewables are already established as the residual unmet demand may not justify the investment. Similarly, off-grid renewables (mainly solar) may not be seen as an option in areas that already have functional mini-grids, unless the load exceeds the availability of electricity from the mini-grid. 
Table 3.2 SE4ALL multi-tier framework against technology options

\begin{tabular}{|c|c|c|c|c|c|}
\hline $\begin{array}{l}\text { Energy access } \\
\text { according to } \\
\text { global tracking } \\
\text { for SE4ALL }\end{array}$ & Basic & \multicolumn{4}{|c|}{ Advanced } \\
\hline Attributes & Tier 1 & Tier 2 & Tier 3 & Tier 4 & Tier 5 \\
\hline Services & $\begin{array}{l}\text { Task light } \\
\text { and phone } \\
\text { charging }\end{array}$ & $\begin{array}{l}\text { General } \\
\text { lighting and } \\
\text { TV and fan }\end{array}$ & $\begin{array}{l}\text { Tier } 2 \text { and any } \\
\text { low-power } \\
\text { appliances }\end{array}$ & $\begin{array}{l}\text { Tier } 3 \text { and any } \\
\text { medium-power } \\
\text { appliances }\end{array}$ & $\begin{array}{l}\text { Tier } 4 \text { and any } \\
\text { higher-power } \\
\text { appliances }\end{array}$ \\
\hline $\begin{array}{l}\text { Peak available } \\
\text { capacity } \\
\text { (minimum W) }\end{array}$ & $3 W$ & $50 \mathrm{~W}$ & $200 \mathrm{~W}$ & $800 \mathrm{~W}$ & $2000 \mathrm{~W}$ \\
\hline $\begin{array}{l}\text { Duration } \\
\text { (minimum hours) }\end{array}$ & 4 & 4 & 8 & 16 & 22 \\
\hline $\begin{array}{l}\text { Evening supply } \\
\text { (minimum hours) }\end{array}$ & 2 & 2 & 2 & 4 & 4 \\
\hline Affordability & & $\sqrt{ }$ & $\sqrt{ }$ & $\sqrt{ }$ & $\sqrt{ }$ \\
\hline Formality (legality) & & & $\sqrt{ }$ & $\sqrt{ }$ & $\sqrt{ }$ \\
\hline Quality (voltage) & & & $\sqrt{ }$ & $\sqrt{ }$ & $\sqrt{ }$ \\
\hline $\begin{array}{l}\text { Indicated minimum } \\
\text { technology }\end{array}$ & $\begin{array}{l}\text { - Nano-grids } \\
\text { - Micro-grids } \\
\text { - Pico-PV/solar } \\
\text { - Lanterns }\end{array}$ & $\begin{array}{l}\text { - Micro-grids } \\
\text { - Mini-grids } \\
\text { - Rechargeable } \\
\text { batteries } \\
\text { - Solar home } \\
\text { systems }\end{array}$ & $\begin{array}{l}\text { - Micro-grids } \\
\text { - Mini-grids } \\
\text { - Home } \\
\text { systems }\end{array}$ & $\begin{array}{l}\text { - Mini-grids } \\
\text { - Grid }\end{array}$ & $\begin{array}{l}\text { - Mini-grids } \\
\text { - Grid }\end{array}$ \\
\hline
\end{tabular}

Source: Adapted from Franz et al. (2014:26)

\section{Business models for stand-alone systems}

Advances in technologies such as solar (photo voltaic or PV system), battery storage and LED lighting and rapidly decreasing prices have led to a growth in standalone electrification solutions in the past ten years. In some cases, growth has been driven by public initiatives, as in the case of the Rural Electrification and Renewable Energy Project in Bangladesh. In others, the uptake has been more private sectordriven, employing upfront cash payment by consumers or through pay-as-you-go (PAYG) schemes or long-term lease models.

Bangladesh is a leading example of deploying solar home systems at scale, reaching over 18 million people from 4.1 million systems installed as of 2017. According to the Infrastructure Development Company Limited (IDCOL), this is expected to save 3.6 million tonnes of kerosene worth $\$ 1300$ million by 2030 (IDCOL, 2018). The Bangladesh government established the IDCOL in the late 1990s to manage and oversee funds obtained from international development finance institutions and donors for infrastructure and renewable energy. Among others, initiatives of the IDCOL focused on developing off-grid energy, including programmes on solar home systems, solar irrigation pumps, solar mini-grids and biogas electricity-based 
production (Oji \& Weber, 2017). IDCOL provides grants and soft loans as well as necessary technical assistance to some 56 partner organisations (POs) who select customers, extend loans, install the systems and provide after-sale service. The POs include overseas development finance institutions, suppliers of SHS, local smalland medium-sized enterprises and microfinance institutions.

African countries can draw important lessons from the experience in Bangladesh on how a government-owned non-bank financial institution can successfully operate a public-private partnership programme to finance off-grid renewable projects. One of the lessons learnt is that the investment management should remain independent of interference and pay attention to market signals. Other lessons learnt are the importance of a single channel for distributing finance and the design of smart subsidies to grow the market. Interest in the IDCOL model is growing among African countries, and in the past few years, a number of experience-sharing and training programmes have been undertaken. By providing the product, the required after-sales service, and the microcredit, the partner organisations in the IDCOL model build trust among consumers.

The recent experience in the PAYG schemes in East Africa resonates well with the Bangladeshi experience in their strong customer-centric focus. Pay-as-you-go involves households or individuals procuring the system from a supplier through a down payment, followed by periodic payments that are set at affordable levels under an arrangement of a perpetual lease or eventual system ownership after a defined period (IRENA, 2018). Table 3.3 describes different types of PAYG schemes.

Table 3.3 Differences among PAYG companies' consumer finance mechanism

\begin{tabular}{|c|c|c|}
\hline Impact & $\begin{array}{l}\text { Rent-to-own } \\
\text { (Product + finance focus) }\end{array}$ & $\begin{array}{l}\text { Long-term lease } \\
\text { (Pure service focus) }\end{array}$ \\
\hline $\begin{array}{l}\text { Impact on } \\
\text { consumers }\end{array}$ & $\begin{array}{l}\text { - Higher regular payments (for equal } \\
\text { product specs) } \\
\text { - Consumer/cultural preference for } \\
\text { ownership } \\
\text { - Theoretical ability to collateralise assets } \\
\text { after they are paid off }\end{array}$ & $\begin{array}{l}\text { - Perpetual service guarantee reduces } \\
\text { warranty anxiety }\end{array}$ \\
\hline $\begin{array}{l}\text { Impact on energy } \\
\text { access challenge }\end{array}$ & $\begin{array}{l}\text { - Raised capital can reach more } \\
\text { customers due to faster cost recovery }\end{array}$ & $\begin{array}{l}\text { - Lower regular payments widen the pool of } \\
\text { potential customers }\end{array}$ \\
\hline $\begin{array}{l}\text { Impact on } \\
\text { companies } \\
\text { or investors }\end{array}$ & $\begin{array}{l}\text { - Shorter duration of cash flows } \\
\text { - Faster recycling of capital towards new } \\
\text { customers } \\
\text { - Broader diversification of debt capital } \\
\text { across a wider customer pool } \\
\text { - Potential for additional income streams } \\
\text { from collateralised assets }\end{array}$ & $\begin{array}{l}\text { - Longer duration of cash flows } \\
\text { - Higher exposure to technology risk } \\
\text { - Higher exposure to company execution risk } \\
\text { - Higher exposure to currency risk } \\
\text { - Stronger customer relationship } \\
\text { - Better opportunities for upselling to larger } \\
\quad \text { systems or appliances }\end{array}$ \\
\hline Examples: & Fenix International, M-KOPA & Off-grid Electric \\
\hline
\end{tabular}

(Source: Orlandi, Tyabji and Chase, 2016:31) 
Payments are made via mobile phones for the electricity consumed and access to electricity can be discontinued in case of non-payment. The strength of the PAYG business model is less about selling electricity in much the same way as utilities or mini-grid operators, but in their focus to provide services such as lighting, communications, information and communications (e.g., mobile charging). Another key attraction in the PAYG schemes relates to the flexible credit facilities tailored to what users can afford and enables them to scale up their solar solutions, products and services. Stand-alone PV systems have been developed in a relatively unregulated market environment and so the barriers to entering the market are reduced and the business case for a profitable business is easier to determine (PricewaterhouseCoopers $[\mathrm{PwC}], 2016$ ).

The firm in a PAYG scheme often plays the three roles of system owner, operator and maintenance provider and bill collector (or a separate company may be brought in to handle customer collections). But what is clear is that as the market has expanded, the firms may build up large portfolios of loans, which are paid in the local currency, while the capital that finances the company may be denominated in international currency (e.g., USD or euros). Therefore, the emerging business models carry currency exchange risks where in the event that the local currency is devalued, an additional cost will be levied that is outside of the business and operations domain. It is therefore important to explore other business models that limit the risk of losses due to potential currency volatility. Some of the market leaders in the PAYG market are firms such as M-KOPA, Mobisol and BBoxx, which operate through hundreds of service centres or retail shops across Kenya, Tanzania, Uganda and Rwanda.

Other business models for the delivery of stand-alone systems also exist. For example, the retail or over the counter model is the most common delivery model for Tier 1 (task lighting and phone charging) products such as the pico lantern (in the \$10-\$20 price range) and pico solar home systems (in the $\$ 100-\$ 200$ price range). Transactions for the pico systems are mostly cash-based, often with shops offering short-term credit to their distributors. Given an average lifetime of products of between three to five years, the viability of the business is dependent on effective marketing, supply and distribution models.

\section{Business models for mini-grids}

Mini-grids are at an earlier stage of development in Africa but given that it is in Africa where access to energy remains lowest, the developments there are of particular interest. For example, according to the IRENA report (2018), Kenya has about $20 \mathrm{MW}$ of operational mini-grids capacity, and Cameroon has over $23 \mathrm{MW}$. 
According to the WRI, Tanzania has become a regional leader in mini-grid development with over 109 mini-grids, amounting to an installed capacity of over $155 \mathrm{MW}$ and serving about 184000 customers. Of the total, 15 percent were connected to the national grid with the remaining 85 percent operating as isolated mini-grids consisting of hydro, biomass, solar and fossil-based systems (cited in Odarno et al., 2017). Mali is another African country that has had some success in developing isolated mini-grids where there are more than 200 mostly small diesel mini-grids in operation in the country. Around 60 of those are privately run and many are in the process of hybridisation ( $\mathrm{PwC}, 2016)$.

Business models for mini-grids can often be classified in terms of the operating or ownership and financing arrangements. The performance of mini-grid operation models will be context-specific and will depend on various factors, such as the investment environment, geography and resources, socio-economic conditions, and the policy/regulatory environment. By their nature, mini-grid developers focus on densely populated areas where there is sufficient load to justify the investment. Four main mini-grid operation models are being implemented in different parts of Africa. These include mini-grids that are utility-operated, privately-operated, community-operated, or hybrids that combine a mix of the others (Table 3.4). It is not unusual for a combination of different actors to be involved, owning or operating different parts of the system, such as the production, distribution and demand management systems. 
Table 3.4 Summary of mini-grid operator models

\begin{tabular}{|c|c|c|c|c|c|}
\hline & Utility models & $\begin{array}{l}\text { Private model } \\
\text { (unregulated) }\end{array}$ & $\begin{array}{l}\text { Private model } \\
\text { (regulated) }\end{array}$ & Hybrid & Community \\
\hline Ownership & Utility & Private & Private & $\begin{array}{l}\text { Private/utility/ } \\
\text { community }\end{array}$ & Community \\
\hline $\begin{array}{l}\text { How it } \\
\text { works }\end{array}$ & $\begin{array}{l}\text { The government } \\
\text { or utility manages } \\
\text { all aspects of the } \\
\text { mini-grid. }\end{array}$ & $\begin{array}{l}\text { A private } \\
\text { company } \\
\text { manages } \\
\text { all aspects, } \\
\text { in the absence } \\
\text { of government } \\
\text { regulation. }\end{array}$ & $\begin{array}{l}\text { A private company } \\
\text { manages all aspects, } \\
\text { in a regulated } \\
\text { environment. }\end{array}$ & $\begin{array}{l}\text { Private actors } \\
\text { generate and } \\
\text { utility distributes } \\
\text { the electricity, } \\
\text { vice versa. } \\
O R \\
\text { Private actors } \\
\text { commercialise } \\
\text { electricity } \\
\text { generated by } \\
\text { and distributed } \\
\text { through public } \\
\text { assets. }\end{array}$ & $\begin{array}{l}\text { Community } \\
\text { members } \\
\text { organise } \\
\text { to manage } \\
\text { generation and } \\
\text { distribution in } \\
\text { a regulated } \\
\text { environment, } \\
\text { with support } \\
\text { and/or } \\
\text { coordination } \\
\text { from an NGO or } \\
\text { private company. }\end{array}$ \\
\hline Pros & $\begin{array}{l}\text { - Can absorb } \\
\text { funds easily } \\
\text { - Less regulation } \\
\text { needed } \\
\text { - Connection } \\
\text { of mini-grid to } \\
\text { main grid can } \\
\text { be easier } \\
\text { - Cross- } \\
\text { subsidisation } \\
\text { of tariffs, thus } \\
\text { affordability } \\
\text { easier ensured } \\
\text { - Aim to fulfil } \\
\text { national } \\
\text { electrification } \\
\text { aims }\end{array}$ & $\begin{array}{l}\text { - Commercial } \\
\text { sustainability } \\
\text { creates } \\
\text { incentives } \\
\text { for long-term } \\
\text { operation } \\
\text { - Can act } \\
\text { fast without } \\
\text { government } \\
\text { interference } \\
\text { - Profitability } \\
\text { ideally allows } \\
\text { for scaling-up } \\
\text { of operations } \\
\text { - Faster pace of } \\
\text { electrification }\end{array}$ & $\begin{array}{l}\text { - Scalability through } \\
\text { private capital } \\
\text { - Technical know- } \\
\text { how, high reliability } \\
\text { - Profitability ideally } \\
\text { allows for scaling- } \\
\text { up operations } \\
\text { - Legal security of } \\
\text { regulated market } \\
\text { attracts private } \\
\text { finance } \\
\text { - Lower subsidy } \\
\text { required }\end{array}$ & $\begin{array}{l}\text { - Different actors } \\
\text { contribute their } \\
\text { strengths, } \\
\text { technical and } \\
\text { management } \\
\text { know-how } \\
\text { - Scalable, } \\
\text { profitable } \\
\text { - Less conflict } \\
\text { potential with } \\
\text { customers } \\
\text { in case of } \\
\text { distribution } \\
\text { by utility } \\
\text { with cross- } \\
\text { subsidised } \\
\text { tariffs }\end{array}$ & $\begin{array}{l}\text { - Design adapted } \\
\text { to community } \\
\text { needs } \\
\text { - Less conflict } \\
\text { potential with } \\
\text { customers and } \\
\text { officials } \\
\text { - Creating assets } \\
\text { and local } \\
\text { ownership and } \\
\text { cooperation } \\
\text { - Enabling self- } \\
\text { determination } \\
\text { and economic } \\
\text { development }\end{array}$ \\
\hline Cons & $\begin{array}{l}\text { - Not the core } \\
\text { business } \\
\text { - Unsuited } \\
\text { company } \\
\text { structure for } \\
\text { smaller projects } \\
\text { - Financial } \\
\text { burden on } \\
\text { utilities } \\
\text { - Possible } \\
\text { political } \\
\text { interference } \\
\text { - Possibly higher } \\
\text { tariffs for main } \\
\text { grid customers; } \\
\text { slower pace of } \\
\text { electrification }\end{array}$ & $\begin{array}{l}\text { - No financial } \\
\text { support from } \\
\text { public sources } \\
\text { - Grid inter- } \\
\text { connection } \\
\text { challenging } \\
\text { - Changes in } \\
\text { regulations } \\
\text { and fixed tariffs } \\
\text { can reduce } \\
\text { profitability } \\
\text { - Possible } \\
\text { conflicts with } \\
\text { customers due } \\
\text { to monopoly } \\
\text { - Insufficient } \\
\text { quality and } \\
\text { safety risks } \\
\text { of service can } \\
\text { occur if it is } \\
\text { not supervised }\end{array}$ & $\begin{array}{l}\text { - Reliable regulation } \\
\text { needed } \\
\text { - Dependency on } \\
\text { lengthy approval } \\
\text { procedures } \\
\text { - Debt financing } \\
\text { needed for } \\
\text { scaling up } \\
\text { - Vulnerable to } \\
\text { changes in } \\
\text { regulation, fixed } \\
\text { tariffs and conflict } \\
\text { with customers } \\
\text { - High transaction } \\
\text { costs } \\
\text { - Potential risk: grid } \\
\text { interconnections }\end{array}$ & $\begin{array}{l}\text { - Complex } \\
\text { management, } \\
\text { feasibility of } \\
\text { models depend } \\
\text { on regional/ } \\
\text { local context/ } \\
\text { structures } \\
\text { - Non-fulfilment } \\
\text { of contracts } \\
\text { due to conflicts } \\
\text { between } \\
\text { business } \\
\text { partners } \\
\text { - Insolvency of } \\
\text { one partner } \\
\text { puts a full } \\
\text { operator model } \\
\text { at risk }\end{array}$ & $\begin{array}{l}\text { - Insufficient } \\
\text { local human } \\
\text { (technical and } \\
\text { management) } \\
\text { capacity } \\
\text { - Often unclear } \\
\text { ownership } \\
\text { structure } \\
\text { - Usually high } \\
\text { grants needed } \\
\text { - Tariffs not } \\
\text { covering } \\
\text { operation and } \\
\text { maintenance } \\
\text { (O\&M) and } \\
\text { reinvestment } \\
\text { costs }\end{array}$ \\
\hline Examples: & Widespread & $\begin{array}{l}\text { Diesel mini-grids } \\
\text { in Somaliland }\end{array}$ & $\begin{array}{l}\text { Powerhive (East } \\
\text { Africa) }\end{array}$ & $\begin{array}{l}\text { Santo Trigo } \\
\text { (Cape Verde); } \\
\text { AMEDER } \\
\text { mini-grids (Mali) }\end{array}$ & $\begin{array}{l}\text { Multi-functional } \\
\text { platform (Mali, } \\
\text { Senegal) }\end{array}$ \\
\hline
\end{tabular}

(Source: Adapted from Orlandi et al., 2016:32) 
In a community-based model, the mini-grid is owned, operated and managed by the community or local non-governmental organisation, normally including maintenance and tariff collection. Mini-grids are typically financed by grants from donors or other external financiers with the local community providing contributions in-kind. Mini-grids tend to set tariffs to only cover operation and maintenance costs, which often means they are budget-constrained and do not generate sufficient profits to scale up. Third parties often carry out the planning and procurement of equipment, installation and commissioning, but the systems are generally operated by local teams. In many cases, local communities lack technical expertise, and the systems may suffer with poor maintenance and lengthy repair times. Small community models require effective social and decision-making structures in the village to prevent conflicts. Larger community-driven cooperative models running generation in the multi-MW scale are more formalised and depend less on local structures (Franz et al., 2014).

In a utility-based model, the national electricity utility owns and operates the mini-grid, which is often run on diesel. The initial financing is usually provided by the national treasury or government or donors. The utility is responsible for the installation, maintenance and operation (and sometimes tariff collection) of the system. This model is the most common for rural electrification in developing countries where, as part of the government's social objectives, the utility may be required to charge tariffs at similar levels as those connected to the national grid. This means that tariffs paid by those connected to the national grid may be used to cross-subsidise those served by the mini-grids, creating difficulties for utilities that may already be cash-constrained (Franz et al., 2014) This has resulted in many mini-grids being poorly maintained and short of funds to allow for a smooth and long-term operation.

Private sector-based models are ones where a private investor establishes, owns and operates the mini-grid system. In some cases, the investor builds the system and transfers it to another actor. Various types of private-sector models include the franchise, the $\mathrm{ABC}$ (Anchor-Business-Community) and the local entrepreneur approaches. Funding usually comes from a mix of private sources, including equity and commercial loans, and public sources such as grants, subsidies or loan guarantees. Such resources from public or grant funds are important to cover part of the project development costs and to keep tariffs at an affordable level for the end-users. However, some purely private-sector models do exist, for example, Powerhive in Kenya was the first private company in Kenya to receive a utility licence to develop, distribute and sell electricity to end-users. This came following Powerhive's successful operation of renewable energy mini-grid projects. The Kenya Power and Lighting Company (KPLC) connected the grid, which served around 1500 rural customers in four villages, including a cluster of users involved in 
commercial activities such as welding, carpentry and milling (World Bank, 2017b). This also means that Powerhive is regulated as a utility, implying that it can access government-sponsored incentives. The collective experiences in mini-grids, not only in Africa but elsewhere, shows that establishing mini-grids in the private sector will require substantial subsidies as well as an anchor load to sustain them.

A hybrid business model combines different aspects of the above three models, depending on a regulatory framework that allows mixed ownership and management. For example, a utility or a private company could implement and own a renewable energy mini-grid power system, while a community-based organisation manages it on a daily basis and a private company provides the technical backup and management advice (Franz et al., 2014). Another model could be that the utility owns and operates the mini-grid distribution assets and a small power producer would own and operate the generation assets. The relationship is transacted through a standard power purchase agreement (PPA), which makes the process of interconnection when the grid arrives easier given that the distribution assets are already owned by the utility and the generation assets can be relocated to another village where there is no grid.

Tenenbaum et al. (2014) classify Small Power Producers (SPPs) based on three characteristics: (i) the fuel or technology used to generate electricity, (ii) whether the SPP is connected to the national grids or operates an isolated mini-grid, and (iii) whether the SPP is selling at retail or wholesale or both. They go on to argue that focusing on the last two characteristics, four types of SPPs can be identified in Africa. Figure 3.5 shows the various combinations where an SPP may sell directly to final customers from an isolated mini-grid, which represents the most common mini-grid business model - a stand-alone, low-voltage distribution grid that is supplied with electricity from one or more small generators connected only to the isolated mini-grid. Another model is where an SPP sells wholesale to the national utility on the main grid but at the same time sells at retail to households and businesses on new mini-grids that are electrically connected to the main grid but operate as separate distribution businesses. 


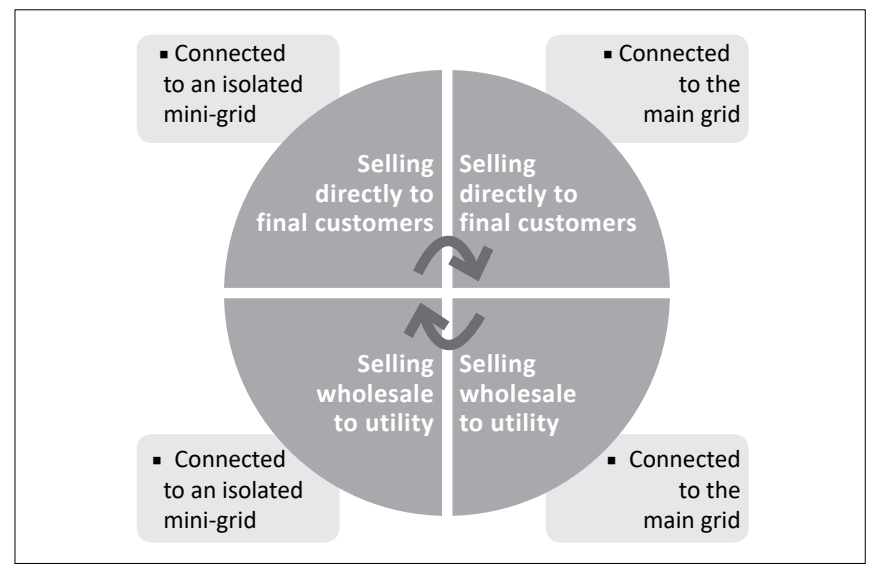

Figure 3.5 Types of electricity sales involving SPPs (Source: Adapted from Tenenbaum et al., 2014:3)

\section{Key barriers for scaling up distributed energy systems}

There are clear opportunities in expecting transformative change. But there are barriers that need to be overcome. The paragraphs that follow consider some of these barriers.

\section{Affordability gap in off-grid systems}

Achieving universal access to energy services by 2030 will necessitate a heavy investment in off-grid systems. Conventional thinking in this area would argue that innovative business models would be needed to mobilise private investment to finance stand-alone or mini grids systems because public subsidies are neither sufficient to address the shortfall or regarded appropriate financing instruments. However, there are two problems with this standpoint. Firstly, there is a significant affordability gap with current technologies for low-income users, namely a gap between cost recovery tariffs and what the users can spend on energy services. For example, even if decentralised PV mini-grids were made available, and even if appliances for basic needs were affordable, the cost of electricity (average cost of $\$ 0.24 / \mathrm{kWh}$ ) to provide basic services with existing appliances may be too high for low-income users (Mitra \& Buluswar, 2015). Hence, either the cost of electricity needs to come down significantly to be affordable or appliances need to become proportionally more efficient, or both need to happen for a similar combined effect. The second problem relates to the inadequacy of money to make subsidies viable for off-grid programmes in the face of massive public support for the fossil fuel industry. In a study for the IMF, Coady, Parry, Sears and Shang (2015) estimated post-tax energy subsidies at $\$ 4.9$ trillion (6.5 percent of global GDP) in 2013 and projected to reach $\$ 5.3$ trillion (6.5 percent of global GDP) in 2015. The study defined fossil fuel subsidies broadly to reflect undercharging for environmental costs and general taxes, as well as production costs. 
This unequal distribution of subsidies creates structural obstacles for off-grid programmes to become established. Whilst business models and private capital are important, carefully targeted public finance will be critical in closing the affordability gap.

\section{Skills and capacity gap}

As countries across Africa are looking to invest in their energy sector to transform their economies, the effectiveness of these efforts will be dependent on the quality (and quantity) of their human resources and institutional capacity. Indeed, meaningful country ownership of programmes means having the requisite and homegrown technical, policy and managerial skills to build and maintain infrastructures. At present, countries in the regions face a critical shortage of handson technical and engineering skills with the ability to build and maintain projects. The result of having too few skilled workers means that energy industries rely on expatriate skills, often with little contextual knowledge, to the detriment of local industries and jobs. Further, Africa lacks its own research and innovation solutions with no coherent national strategy across the region to address the system-wide gap in skills in the energy sector. Part of the practical steps that could be taken would involve improving the conditions of vocational and knowledge institutions, building in the right incentive structures for those within, and exploring workable and lasting partnerships.

\section{Weak policy environment out of step with developmental ambitions}

Most countries in the region have embarked on ambitious development plans to boost growth in agriculture, manufacturing and services to create jobs and raise living standards. However, in many cases, these aspirations for transformative change have not been matched by correspondingly bold policies on energy. If anything, energy policymakers appear stranded in their traditional incremental approaches and assumptions, oblivious to the fact that the world around them has changed markedly - it has become more interconnected and more complex. Economic growth trends and social expectations are such that major energy transitions are demanded that take into account environmental and climate change considerations. Furthermore, the consensus around the 2030 commitment of 'energy for all' requires the adoption of strategies that extend the provision of energy that can be reached through a combination of centralised (grid) and decentralised options (APP, 2015). Part of the rationale for this diversified perspective is that off-grid options are now mature and competitive and unserved households should no longer have to wait 15 to 20 years until grid-connection eventually arrives. The technology and cost rationale for inadequate access to modern energy no longer applies. 


\section{Lack of coherent public-private partnership}

The nature of technological and market developments in recent years has underlined the continued importance of the state as a facilitator and guardian of good policies as well as an investor in energy systems. This means that policymakers need to recognise the emergence of the private sector as a major player that requires a stable policy and regulatory landscape to invest in the energy market. However, whilst much of this is intended to enhance the confidence of foreign investors, domestic entrepreneurs are likely to play a pivotal role in growing the overall investment envelope. Hence, the question around how to mobilise domestic entrepreneurs and national financial institutions to be responsive to the social agenda of clean energy access and conducive investment opportunities is critical. Incentivising these domestic actors to enter the energy market has additional benefits, namely they understand the national business context and carry lower risk thresholds. To date, there has been limited dialogue to engage these actors and establish clear roles for them to play in the development of the region's energy future.

\section{Governance structure is at odds with policies}

The development of policies and regulations is important, but their mere existence is not sufficient for achieving successful outcomes. The history of power sector reform in Africa is replete with missed opportunities and disappointing results, since reforms had mainly been founded on a false 'epistemology'. The architects of these early reforms viewed the problem through a techno-economiclens, neglecting the broader socio-political context and the essential institutional elements that are representative of the system (Thompson \& Bazilian, 2013). Sectoral reforms do not take place in a societal vacuum, but rather are shaped by the political economy terrain that underpins them. To this end, the level of active commitment by government and other stakeholders is fundamental to ensure that plans have been developed in step with related policy areas and with the full participation of the national political institutions.

\section{Discussion: Criteria for success}

The debate about the drivers and consequences of energy poverty and lack of access has been raging for over four decades. It is now all too evident that countries in Africa need sustainable energy master plans that consider current and future demands, the mix of resources and infrastructures, as well as scales that are appropriate to each country context. Plans must also incorporate social, environmental and climate concerns to ensure infrastructures are resilient and the services they provide are inclusive. Part of this relates to the fact that energy systems cannot be treated in isolation from the wider development agenda and the underlying political and institutional structures. Of course, in envisioning 
such a comprehensive approach, several questions emerge. What makes us think that it is different this time around? What has changed in the landscape of our policies and innovation systems to expect different outcomes against a litany failed experiments? This section will provide some of the reasons for a new sense of optimism, supported by cases from the region.

\section{Policy instruments need to be transparent and fit national conditions}

Costs for new energy options are falling and technologies such as wind turbines and grid-based PV systems are becoming competitive. However, the success of implementation depends on the viability of technologies and suitability of policies for encouraging the integration of renewable energy supplies into the energy system. To this end, debates have intensified on the most effective policy instruments to accelerate public-private partnerships and stimulate private sector investment in grid-connected renewable technologies. Feed-in tariffs (FiTs) have been the most widely used government support mechanism for accelerating private investment in renewable energy generation. One encouraging initiative is Uganda's Global Energy Transfer Feed-in Tariff (GET FiT) programme, formally launched in May 2013, which has demonstrated how the instrument can be deployed successfully in an African context to finance smaller-scale projects. The first two rounds of 'Request for Proposals' have resulted in 15 projects with a planned installed capacity of $128 \mathrm{MW}$, and a promising pipeline for the third Request for Proposals that may increase the portfolio to 20 projects (Eberhard, Kolker \& Leigland, 2014).

Competitive tenders or auctions have also emerged in various countries as acceptable instruments, especially in emerging economies. South Africa's Renewable Energy Independent Power Producer Procurement Programme (REIPPP) is an outstanding example of this scheme. This programme enables the utility, ESKOM, to enter into a PPA allowing Independent Power Producers (IPPs) make firm revenue projections. The guaranteed power off-take by ESKOM provides the foundation for this highly successful and rapidly growing renewable energy programme. According to the United nations Food and Agriculture Organization (FAO), REIPPP has generated 64 new renewable energy IPPs, attracting US\$14 billion in investment for the construction of $3922 \mathrm{MW}$ of capacity in technologies like gridconnected wind, PV, and to a lesser degree, hydro, landfill gas and biomass energy (FAO, 2011). REIPPP offers many valuable lessons on how other countries in the region procure renewable energy projects rapidly and effectively. It also highlights the importance of strong banking, legal and other advisory resources in rolling out effective renewable energy programmes. 


\section{Sustained political leadership is fundamental for success}

Good governance enhances the ability of any nation to reach its full economic and social development potential. This means that governance must be strong at each level, in order for countries to maintain rates of growth in an inclusive manner. One common feature is that every country that has achieved universal access has reached this goal with the support of strong leadership that can establish a common vision of the benefits of enhanced energy systems for growth and wellbeing. Leadership is critical to drive through comprehensive long-term planning in partnership with public, private and civil society stakeholders. At present, Africa lacks public administration systems that embody long-term visions, and most planning has short-term horizons and little value for laying the foundation for a sustainable energy transition.

This picture is gradually changing though and propelled by new technologies, policy reforms and innovative business models, several countries are experimenting with new pathways. Ethiopia is one of these countries that has registered rapid economic growth over the past decade and has spent considerable political and financial capital in renewable energy development as integral to its Growth and Transformation Plan. Two parallel visions characterise Ethiopia's energy plans. On the domestic front, the policymakers recognise electricity as a vital enabler of economic growth and human development, aiming to minimise the gap between demand and supply by increasing hydropower and renewable capacity from $2000 \mathrm{MW}$ to over $10000 \mathrm{MW}$ and raise national electrification rate by 75 percent. On the regional scale, the country aims to generate power for export to become one of the major contributors to the East African Power Pool. Much of the investment for this ambitious expansion programme comes from finances mobilised from local sources and concessionary loans, which is a reflection of the political imperative of economic transformation.

\section{Agroforestry as an energy opportunity}

Bio-energy will remain an important source of energy for African households, with demand continuing to grow. Assuming bio-energy production from non-sustainable forests, which is mostly the case in much of Africa, the rate of deforestation and net GHG emissions, particularly for charcoal production, is significant (World Bank, 2011). The charcoal industry in sub-Saharan Africa had an estimated value of approximately $\$ 8$ billion in 2007 . Whilst there are investment opportunities in industrial plantations, agroforestry, as an integrated strategy together with improved kilns and stoves, can have a significant impact on the reduction of wood harvest pressures in forests. Advances in agroforestry science and innovations are providing farmers with greater species options and more resilient systems for tree developments on farmland. 
There are numerous initiatives from multilateral organisations and from the private sector with innovative business models aimed at improving agricultural productivity for food and creating bioenergy development opportunities. Many of these initiatives have highlighted improvements in household wealth and income diversity, resulting from the sale of fuelwood and other tree products. More critically, agroforestry activities provide labour savings to women household members by reducing time spent on fuelwood collection. Thus, while there are clear benefits associated with agroforestry practices in terms of delivering income and wellbeing, one critical challenge is overcoming the length of time (often three to four years) when farmers are making initial investments (land and inputs). Improving access to loans and farm implements enables farmers to see tangible benefits in the short-term before their trees have matures and able to yield financial and livelihoods benefits.

\section{National entrepreneurs and business models are critical for unlocking internal investment}

Given its abundant natural resources and the many innovative environment-related financing instruments available today, Africa has the opportunity to take advantage of these opportunities and pursue a clean energy path. The involvement of the domestic private sector will be a critical requirement. There is currently a vigorous discussion among local entrepreneurs across Africa on how to help fill the gap in power generation, especially in off-grid generation. This conversation is not only about investing their money in energy, but also how to leverage additional finance from external sources in support of strong growth, job creation, and poverty reduction on the continent.

There are a several initiatives such as the US Government Power Africa initiative, which is designed to support African entrepreneurs to enter the energy market. Through this programme, a growing number of entrepreneurs are getting seed money to develop commercially viable ways to deliver power to unserved, often rural communities. A broad array of solutions is being developed in Ghana, Ethiopia, Liberia, Tanzania, Kenya and Nigeria, creating incubators for greater innovation. Sustaining such initiatives will be predicated on the ability of local entrepreneurs to raise sustainable finance for maintaining their activities from commercial banks to provide the necessary financing to grow the off-grid energy sector. For this to happen, innovative business models such as the 'pay-as-you-go' models would need to be mainstreamed and the level of risk perceived by investors is reduced. Fundamental to this is for entrepreneurs to demonstrate robust profit margins to service their loans, and for government to create stable regulatory and policy environment. Today, a growing number of companies are operating in at least 20 sub-Saharan African countries that use digitally-financed off-grid electricity services (Welsch et al., 2013). 


\section{Agro-industry-based co-generation as a local solution}

Agro-industries account for a major source of rural employment and are significant contributors to the economy of many sub-Saharan African countries. Agroindustries in this region, such as tea, coffee and sugar estates, already utilise energy for their processing and, on occasions, supply energy to their employees within their estates. In the event of non-access to the grid, scaling up electricity service would have direct economic and social benefits to rural communities in the vicinity of these estates, and offer the agro-businesses a potentially attractive commercial opportunity for diversifying into the energy market. Where the industry is connected to the grid, feeding into the grid in times of surplus and drawing from it when supplies are low makes it very likely that communities will have access to electricity. The two ways that agro-industries relate to the energy system and influence the outcome in regards to widening energy access are different - the off-grid case requires an active engagement in investment and delivery, while the grid-based model requires a more passive engagement.

Mauritius is an African success story in co-generation. The sugar industry in Mauritius is currently self-sufficient in electricity and sells the excess it generates to the national electricity grid. The industry contributes about 16 percent of the electricity supply on the island. The importance of revenue from the sale of excess electricity from co-generation is such that it has enabled Mauritian sugar factories to remain profitable. A notable achievement has been the use of a wide variety of innovative revenue-sharing measures where the island's co-generation industry has worked closely with the government to ensure that substantial monetary benefits from the sale of electricity from co-generation are shared by all key stakeholders of the sugar economy, including the poor smallholder sugar farmers. There are three main success factors of the Mauritian programme: (i) from the outset the government has played an instrumental role in putting in place strong policies and clear regulations, (ii) the involvement of local private entrepreneurs in IPP initiatives allowed for the IPP development to piggy-back on the locally owned sugar industry, and (iii) consultations with all relevant stakeholders allowed for a negotiated and equitable revenue sharing formula.

\section{Strengthened capacity as a prerequisite to attract investment}

It is evident by now that three common problems bedevil new energy enterprises from entering the energy market: lack of investment finance, weak enabling policies and regulations, and inadequate skills and capacity. There is new thinking today that the success of projects (and programmes) should be measured in accordance with how well they create opportunities for skills and capacity within the countries. This is especially needed in areas where there is a lack of the technical, financial, and legal skills needed to deliver bankable feasibility studies and bring projects to 
completion. Introducing new skills, know-how, and technologies into the energy industry will help to enable the benchmarking of performance and enhance the share of local value in the supply chain. This will facilitate innovations to reduce costs and improve efficiencies.

\section{Conclusion}

Africa is a continent under transformation, in terms of economic performance, demographic changes as well as settlement patterns towards more urbanisation. In connection with this, Africa's energy demands are increasing, and its energy mix are changing, creating the openings for innovations in technologies and policies as well as finance to manage the range of energy transitions across the continent.

This chapter has attempted to grapple with the long-standing challenge of persistent energy poverty and how it impacts on development outcomes in Africa. The chapter demonstrates that energy issues across sub-Saharan Africa are inherently complex, largely due to the dual nature of the energy system itself where traditional and modern energy systems and practices co-exist. One of the key characteristics of this dichotomy is that a large proportion of people in Africa live without access to electricity with the majority of them living in rural areas, which adds to the complexity and structural disadvantage that many citizens face across most countries. Whilst there is a growing consensus globally that the future of the energy systems should be fairer, cheaper, cleaner and climate-friendly, this has particular relevance for Africa where investment in infrastructure and systems must reflect the hopes and aspirations of people and communities. To this end, African leaders and their policymakers are making long-term decisions on infrastructure and services that will determine the character of their energy systems over the coming decades.

The chapter stresses that widening energy access is critical for social and economic transformation and to meet many of the SDGs. But Africa needs to be in control of its destiny and direction to ensure the solutions are compatible with the reality on the ground and offer genuine solutions to communities. For this, policies matter, governance is critical and understanding of context is paramount. However, even with all the diversity across the region, there are many good reasons why the clean energy route makes sense, even for those that have plenty of fossil fuel reserves. Some of these reasons are detailed below:

The continent is richly endowed with green and renewable sources of energy. At the same time, there cannot be any talk of structural economic transformation without a massive increase in the electricity generation, and what better way is there than to generate the electricity from the abundant resources found in the continent. 
Agriculture will remain the mainstay of most African economies into the future. As such, Africans need to think hard about modernising the way agriculture is done with a view to enhancing productivity. This includes investing in energy for irrigation, processing and transport for the benefit of smallholder farmers. Much of this would be in the form of modular type energy systems that can be adapted to changing demand, thereby optimising the size of the systems.

The world has seen rapid cost reduction in renewable energy technologies in recent years, in particular of solar and wind energy systems. Together with energy-efficiency measures, renewables offer real opportunities to change the narrative around energy access for the poor. This can create economic and job opportunities and improve air quality and contribute to climate change mitigation, thereby delivering significant human health and sustainable development co-benefits. African countries need to create enabling conditions to take advantage of these opportunities.

Investment in clean energy has grown rapidly in recent years. In 2013, for the first time, the world added more low-carbon electricity capacity than fossil fuel capacity, and over the next 15 years, about US $\$ 90$ trillion will be invested in infrastructure in the world's cities, agriculture and energy. Africa cannot afford to miss out on these investment opportunities.

This chapter recognises that large-scale energy systems will still be important in the energy mix of African countries, and already significant resources and policy attention is devoted to such systems. However, distributed energy systems also offer serious prospects for the vast numbers of people in settlements far from grid lines and without access to energy. The chapter makes a strong argument for scaling up such systems, pointing to the fact that the past few years have seen the coming of age of distributed generation and mini-grids that are successfully extending electricity access to households, communities, cooperatives, small- and medium-sized enterprises, as well as larger companies. This enables producers and consumers of energy to collaborate meaningfully through small and locally-based systems to provide energy services for a variety of social and economic needs. Creating the policy environment, financing models, as well as appropriate institutions, will be critical to enable these bottom-up energy innovations to flourish. This chapter has attempted to ask deeper questions about efficiency of resource use, social justice as well as economic resilience associated with energy systems of the future in Africa. 


\section{References}

Africa Progress Panel. (2015). Power, people, planet: Seizing Africa's energy and climate opportunities. Africa progress report 2015. Geneva: APP.

Allen, M.R., Dube, O.P., Solecki, W., AragónDurand, F. \& Cramer, W. et al. (2018). Framing and Context. In: V. MassonDelmotte, P. Zhai, H.-O. Pörtner, D. Roberts \& J. Skea et al. (Eds). Global Warming of $1.5^{\circ} \mathrm{C}$. An IPCC Special Report on the impacts of global warming of $1.5^{\circ} \mathrm{C}$ above pre-industrial levels and related global greenhouse gas emission pathways, in the context of strengthening the global response to the threat of climate change, sustainable development, and efforts to eradicate poverty.

Bailis, R., Drigo, R., Ghilardi., A. \& Masera, O. (2015). The carbon footprint of traditional woodfuels. Nature Climate Change 5: 266-272. https://doi.org/10.1038/ nclimate 2491

Bardouille, P., Avato, P., Levin, J., Pantelias, A. \& Engelmann-Pilger, H. (2012). From gap to opportunity: Business models for scaling up energy access. Washington, DC: International Finance Corporation/ World Bank.

Boden, T.A., Marland, G. \& Andres, R.J. (2017). Global, regional, and national fossil-fuel $\mathrm{CO}_{2}$ emissions. Oak Ridge, TN: Carbon Dioxide Information Analysis Center, Oak Ridge National Laboratory, U.S. Department of Energy. https://doi. org/10.3334/CDIAC/00001_V2017 [Accessed 18 September 2019].

Brander, M., Sood, A., Wylie, C., Haughton, A. \& Lovel, J. (2011). Technical paper / Electricity-specific emission factors for grid electricity. Ecometrica. https://bit. ly/31cu7HW [Accessed 1 October 2019].

Bruckner T., I.A., Bashmakov, I.G., Mulugetta, Y., Chum, H., de la Vega Navarro, A. et al. (2014). Energy systems. In: O. Edenhofer, R. Pichs-Madruga, Y. Sokona, E. Farahani, S. Kadner et al. (Eds), Climate change 2014: Mitigation of climate change. Contribution of working group III to the fifth assessment report of the intergovernmental panel on climate change. New York: Cambridge University Press.

Castellano, A., Kendall, A., Nikomarov, M. \& Swemmer, T. (2015). Brighter Africa: The growth potential of the sub-Saharan electricity sector Africa. https://mck. co/2MFSjgD [Accessed 22 July 2018.

Coady, D., Parry, I. Sears, L. \& Shang, B. (2015). How large are global energy subsidies? IMF Working Paper WP/15/105, International Monetary Fund. https://doi. org/10.5089/9781513532196.001

Daly, H.E. (1993). Sustainable growth: An impossibility theorem. In: H.E. Daly \& K.N. Townsend, Valuing the earth: Economics, ecology, ethics. Cambridge, MA: The MIT Press.

Dharmadhikary, S. \& Bhalerao, R. (2015). How much energy do we need: Towards end-use based estimation for decent living. Pune, India: Prayas (Energy Group).

Eberhard, A., Kolker, J. \& Leigland, J. (2014). South Africa's renewable energy IPP procurement programmes: Success factors and lessons. Washington, DC: The World Bank Group.

Falcone, P.M. (2014). Sustainability transitions: A survey of an emerging field of research. Environmental Management and Sustainable Development 3(2): 61-83. https://doi.org/10.5296/emsd.v3i2.6239

Fleurbaey, M., Kartha, S., Bolwig, S., Chee, Y.L., Chen, Y. et al. (2014). Sustainable development and equity. In: O. Edenhofer, R. Pichs-Madruga, Y. Sokona, E. Farahani, S. Kadner et al. (Eds), Climate change 2014: Mitigation of climate change. Contribution of working group III to the fifth assessment report of the intergovernmental panel on climate change. New York: Cambridge University Press. 
Food and Agriculture Organization of the United Nations. (2011). Highlights on wood charcoal: 2004-2009. Rome: FAO Forestry Department. https://bit. ly/2OF1il7 [Accessed 15 March 2018].

Foster, C. \& Heeks, R. (2015). Policies to support inclusive innovation. Manchester Centre for Development Informatics Working Paper No. 61, University of Manchester. https://doi.org/10.2139/ ssrn.3433962

Franz, M., Peterschmidt, N., Rohrer, M. \& Kondev, M. (2014). Mini-grid policy toolkit: Policy and business frameworks for successful mini-grids roll out. Eschborn, Germany: EU Energy Initiative Partnership Dialogue Facility EUEI-PDF. https://bit.ly/2ph16xF [Accessed 21 July 2018].

Fuso-Nerini, F., Tomei, J., To, L.S., Bisaga, I., Parikh, P. et al. (2018). Mapping synergies and trade-offs between energy and the sustainable development goals. Nature Energy 3: 10-15. https://doi.org/10.1038/ s41560-017-0036-5

Geels, F.W. (2005). Technological transitions and system innovations. A co-evolutionary and socio-technical analysis. Cheltenham, UK: Edward Elgar Publishing Ltd. https://doi. org/10.4337/9781845424596

Geels, F.W., Kern, F., Fuchs, G., Hinderer, N., Kungl, G. et al. (2016). The enactment of socio-technical transition pathways: A reformulated typology and a comparative multilevel analysis of the German and UK low-carbon electricity transitions (1990-2014). Research Policy 45(4): 896-913. https://doi.org/10.1016/j. respol.2016.01.015

Goldemberg, J., Johansson, T.B., Reddy, A.K.N. \& Williams, R.H. (1985). Basic needs and much more with one kilowatt per capita. Ambio 14(4/5): 190-200. https://bit. ly/2nGtSr1 [Accessed 15 October 2018].

Harlan, S.L., Pellow, D.N., Roberts, J.T., Bell, S.E., Holt, W.G. et al. (2015). Climate justice and inequality. In: R.E. Dunlap
\& R.J. Brulle (Eds), Climate change and society: Sociological perspectives. New York: Oxford University Press. https://doi.org/10.1093/acprof:o so/9780199356102.003.0005

Hiremath, R., Shikha, S. \& Ravindranath, N. (2007). Decentralized energy planning; modeling and application - a review. Renewable and Sustainable Energy Reviews 11(5): 729-752. https://doi.org/10.1016/j. rser.2005.07.005

Hogart, J.R., Haywood, C. \& Whitley, S. (2015). Low carbon development in sub-Saharan Africa. London: Overseas Development Institute Report, ODI.

Humphreys, S. (2017). Climate, Technology, Justice. In: A. Proelß (Ed.), Protecting the Environment for Future Generations - Principles and Actors in International Environmental Law. Berlin: Erich Schmidt Verlag.

Iiyama, M., Neufeldt, H., Dobie, P., Njenga, M., Ndegwa, G. et al. (2014). The potential of agroforestry in the provision of sustainable woodfuel in sub-Saharan Africa. Current Opinion in Environmental Sustainability 6: 138-147. https://doi.org/10.1016/j. cosust.2013.12.003

Infrastructure Development Company Limited. (2018). Project and programmes: Solar home system programme, IDCOL, Dhaka. https://bit.ly/318gv0t [Accessed 10 November 2018].

International Energy Agency. (2014). Africa energy outlook - A focus on energy prospects in sub-Saharan Africa. Paris: IEA.

International Institute for Environment and Development. (2012). What is the sustainable energy for all initiative? https://bit.ly/2plnwO9 [Accessed 2 September 2019].

International Monetary Fund. (2019). Regional economic outlook: Sub-Saharan Africa, April 2017. Washington, DC: IIED. https://bit. ly/2q8nv0x [Accessed 28 April 2019]. 
International Renewable Energy Agency. (2015). Off-grid renewable energy systems: Status and methodological issues. IRENA Working Paper, IRENA, Abu Dhabi, UAE. https://bit.ly/2q2MQZI [Accessed 12 August 2018].

International Renewable Energy Agency. (2016). Solar PV in Africa: Costs and markets. https://bit.ly/35oxlga [Accessed 2 August 2018].

International Renewable Energy Agency. (2018). Off-grid renewable energy solutions. https://bit.ly/33vKb9B [Accessed 15 October 2018].

Kemp, R. \& Loorbach, D. (2006). Transition management a reflexive governance approach. In: J-P. Voss, D. Bauknecht \& R. Kemp (Eds), Reflexive governance for sustainable development. Cheltenham, UK: Edward Edgar Publishing.

Least Developed Countries Renewable Energy and Energy Efficiency Initiative. (2018). LDC REEEI: By LDCS for LDCS. http:// ldcreeei.org [Accessed 1 October 2019].

Loorbach, D. (2010). Transition management for sustainable development: A prescriptive, complexity-based governance framework. Governance: An International Journal of Policy, Administration, and Institutions 23(1):161-183. https://doi.org/10.1111/ j.1468-0491.2009.01471.x

Lovins, A.B. (1977). Soft energy paths: Towards a durable peace. Cambridge, MA: Ballinger Publishing Company and Friends of the Earth International.

Lucas, P.L., Nielsen, J., Calvin, K., McCollum, D.L., Marangoni, G. et al. (2015). Future energy system challenges for Africa: insights from Integrated assessment models. Energy Policy 86: 705-717. https://doi.org/10.1016/j. enpol.2015.08.017

Mitra, S. \& Buluswar, S. (2015). Universal access to electricity: Closing the affordability gap. Annual Review of Environmental Resources 40: 261-283. https://doi.org/10.1146/annurevenviron-102014-021057
Mulugetta, Y., Ben Hagan, E. \& Kammen, D. (2019). Energy access for sustainable development. Environmental Research Letters 14(2): 1-6. https://doi. org/10.1088/1748-9326/aaf449

Mulugetta, Y. \& Castan-Broto, V. (2018). Deep mitigation opportunities and urbanization patterns in LDCs. Current Opinion in Environmental Sustainability 30: 82-88. https://doi.org/10.1016/j. cosust.2018.03.007

Odarno, L., Sawe, E., Swai, M., Katyega, M.J.J. \& Lee, A. (2017). Accelerating mini-grid deployment In sub-Saharan Africa: Lessons from Tanzania. World Resources Institute and TaTEDO. https://bit.ly/32a0RmM [Accessed 10 October 2018].

Oji, C. \& Weber, O. (2017). Beyond the grid: Examining business models for delivering community-based REPs in developing countries. CIGI Paper No. 130, Centre for International Governance Innovation, Waterloo, Canada.

Okereke, C. (2010). Climate justice and the environmental regime. Wiley Interdisciplinary Reviews: Climate Change 13: 462-474. https://doi.org/10.1002/ wcc. 52

Okereke, C., Coke, A., Geebreyesus, M., Ginbo, T., Wakeford, J. et al. (2019). Governing green industrialisation in Africa: Assessing key parameters for a sustainable socio-technical transition in the context of Ethiopia. World Development 115: 279-290. https://doi.org/10.1016/j. worlddev.2018.11.019

Orlandi, I., Tyabji, N. \& Chase, J. (2016). Off-grid solar market trends report 2016. https://bit.ly/2CqPpcE [Accessed 18 September 2019].

Pachauri, S., van Ruijven, B.J., Nagai, Y., Riahi, K., van Vuuren, D.P. et al. (2013). Pathways to achieve universal household access to modern energy by 2030 . Environmental Research Letters 8(2): 024015. https://doi.org/10.1088/17489326/8/2/024015 
Pezzey, J. (1992). Sustainable development concepts: An economic analysis. Washington, DC: World Bank. https://doi. org/10.1596/0-8213-2278-8

Practical Action. (n.d.). Total energy access is achievable - Infographic. https://bit. ly/2ouhv1U [Accessed 1 October 2019]. https://doi.org/10.3362/9781780449357

Practical Action. (2010). Poor people’s energy outlook 2010. Rugby, UK: Practical Action Publishing.

Practical Action. (2016). Poor people’s energy outlook 2016: National energy access planning from the bottom up. Rugby, UK: Practical Action Publishing.

PricewaterhouseCoopers. (2016). Electricity beyond the grid: Accelerating access to sustainable power for all. https://pwc.to/33C1rdp [Accessed 19 September 2019].

Raven, R., van den Bosch, S. \& Weterings, R. (2010). Transitions and strategic niche management: Towards a competence kit for practitioners. International Journal of Technology Management 51(1): 57-74. https://doi.org/10.1504/ IJTM.2010.033128

Ribera, T., Sachs, J., Colombier, M., SchmidtTraub, G., Waisman, H. et al. (2015). Pathways to deep decarbonization. New York: SDSN/IDDRI.

Robbins, P. (2004). Political ecology. London: Blackwell Publishing.

Roberts, J.T. \& Parks, B. (2006). A Climate of injustice: Global inequality, north-south politics, and climate policy. Cambridge, MA: MIT Press.

Sen, A. (2000). Development as freedom. New York: Alfred A. Knopf.

Showers, K.B. (2011). Electrifying Africa: An environmental history with policy Implications. Geografiska Annaler Series B Human Geography 93(3): 193-221. https://doi.org/10.1111/j.14680467.2011.00373.x
Shue, H. (2013). Climate hope: Implementing the exit strategy. Chicago Journal of International Law 13(2): 380-402. https://bit.ly/35yjNxl [Accessed 12 September 2019].

Sokona, Y., Mulugetta, Y. \& Gujba, H. (2012). Widening energy access in Africa: Towards energy transition. Energy Policy 47, Suppl. 1: 3-10. https://doi.org/10.1016/j. enpol.2012.03.040

Tenenbaum, B., Greacen, C., Siyambalapitiya, T. \& Knuckles, J. (2014). From the bottom up: How small power producers and mini-grids can deliver electrification and renewable energy in Africa. Directions in Development. Washington, DC: World Bank. https://bit.ly/lg4PspF [Accessed 20 September 2019]. https://doi. org/10.1596/978-1-4648-0093-1

Thompson, G. \& Bazilian, M. (2013). Democratization, energy poverty, and the pursuit of symmetry. Global Policy 5(1): 127-131. https://doi.org/10.1111/17585899.12103

United Nations Department of Economic and Social Affairs. (2015). World population prospects: 2015 revision. Geneva: UNDESA. https://bit.ly/2OF2Bk1 [Accessed 2 October 2019].

United Nations Environment Programme. (2017). Atlas of Africa energy resources. Nairobi: UNEP. https://bit.ly/2otNVJW [Accessed 28 April 2019].

United Nations Framework Convention on Climate Change. (2016). Aggregate effect of the intended nationally determined contributions: An update. https://bit. ly/2VBDTSS [Accessed 1 October 2019].

Wang, Y.-D. (2001). Development of an alternative energy system: The challenge and its future. In: H-K. Kim, Energy and Korean Life. Seoul: Korean Future Society.

Welsch, M., Bazilian, M., Howells, M., Divan, D., Elzinga, D. et al. (2013). Smart and just grids for sub-Saharan Africa: Exploring options. Renewable and Sustainable Energy Reviews 20: 336-352. https://doi.org/10.1016/j.rser.2012.11.004 
World Bank. (2011). Wood-based biomass energy development for sub-Saharan Africa: Issues and approaches. Washington, DC: World Bank. https://doi.org/10.15 96/26149

World Bank. (2017a). Mini-grids in Cambodia: A case study of a success story. Energy Sector Management Assistance Program. Washington, DC : World Bank Group. https://bit.ly/35uM7Rf [Accessed 18 September 2018].

World Bank. (2017b). Mini-grids in Kenya: A case study of market at a turning point. Energy Sector Management Assistance Program. Washington, DC: World Bank Group. https://bit.ly/2OJzRXp [Accessed 20 October 2018].
World Bank. (2017c). State of electricity access report 2017. Washington, DC: World Bank.

World Bank. (2018). Tracking SDG7: The energy progress report. Washington, DC: World Bank.

World Commission on Environment and Development. (1987). Our common future. New York: United Nations.

World Economic Forum. (2019). Fostering effective energy transition. Geneva: World Economic Forum.

World Resources Institute. (2014). Climate analysis indicators tool-CAIT 2.0. https://bit.ly/2B6ZxFf[Accessed 18 September 2019]. 